Federal Reserve Bank of Dallas

Globalization and Monetary Policy Institute

Working Paper No. 135

http://www.dallasfed.org/assets/documents/institute/wpapers/2013/0135.pdf

\title{
International Trade Price Stickiness and Exchange Rate Pass-through in Micro Data: A Case Study on US-China Trade
}

Mina Kim

Bureau of Labor Statistics

Jian Wang

Federal Reserve Bank of Dallas
Deokwoo Nam

City University of Hong Kong

Jason Wu

Federal Reserve Board

January 2013

Revised: August 2013

\begin{abstract}
The interaction between the exchange rate regime, trade firms' price-setting behavior, and exchange rate pass-through (ERPT) is an important topic in international economics. This paper studies this using a goods-level dataset of US-China trade prices collected by the US Bureau of Labor Statistics. We document that the duration of US-China trade prices has declined almost 30\% since China abandoned its hard peg to the US dollar in June 2005. A benchmark menu cost model that is calibrated to the data can replicate the documented decrease in price stickiness. We also estimate ERPT of RMB appreciation into US import prices between 2005 and 2008. Goods-level data allows us to estimate that the lifelong ERPT is close to one for goods that have at least one price change, but less than one-half when all goods are included. This finding can be attributed to the fact that around $40 \%$ of the goods never experience a price change, and supports the hypothesis that price changes that take the form of product replacements may bias ERPT estimates downwards.
\end{abstract}

JEL codes: E31, F14, F31

\footnotetext{
* Mina Kim, Bureau of Labor Statistics, Postal Square Building, Room 3105, 2 Massachusetts Avenue, NE, Washington, DC 20212. 202-691-6596. minakim@mkecon.com. Deokwoo Nam, Department of Economics and Finance, City University of Hong Kong, Tat Chee Avenue, Kowloon, Hong Kong. +8523442-7298. deokwnam@cityu.edu.hk. Jian Wang, Research Department, Federal Reserve Bank of Dallas, 2200 N. Pearl Street, Dallas, TX 75201. 214-922-6471. jian.wang@dal.frb.org. Jason Wu, Board of Governors of the Federal Reserve System, 20th Street and Constitution Avenue, NW, Washington, DC 20551. 202-452-2556, Jason.j.wu@frb.gov. We thank Bill Alterman, Mick Devereux, Mathias Hoffmann, David Mead, Emi Nakamura, Rozi Ulics, and seminar participants at various seminars and conferences for comments. Part of the research for this project was conducted while Jian Wang was a visiting research fellow at the Hong Kong Institute for Monetary Research, whose hospitality is greatly appreciated. We would also like to thank Taylor Blackburn, Marisa Gudrais, and Jojo Zhao for excellent research assistance. The views in this paper are those of the authors and do not necessarily reflect the views of the Bureau of Labor Statistics, the Federal Reserve Bank of Dallas or the Federal Reserve System.
} 


\section{Introduction}

China's abandonment of its hard currency peg to the US dollar in June 2005 provides an excellent opportunity to study the impact of exchange rate policy on the price setting behavior of firms in international trade. We are interested in two questions in this paper. First, how has the pricing behavior of Chinese and US exporters changed since 2005? Second, how much of RMB appreciation between 2005 and 2008 has passed on to US import prices (exchange rate pass-through, or ERPT)?

These two questions are important in the context of China's large current account surplus with the US and the view that this surplus has played a large role in global economic imbalances. Indeed, several prominent policymakers and economic researchers have pressed China to revalue its currency in order to rebalance the global economy. ${ }^{1}$ The ERPT question is particularly important in this debate, as a fundamental assumption driving the argument for an RMB revaluation is that the ERPT of RMB appreciation into US import prices is high. However, this assumption was not supported by aggregate price data. Recognizing that heterogeneity in pricing behavior is not reflected through aggregate prices, we use goods-level micro data of US-China trade prices collected by the US Bureau of Labor Statistics (BLS) to shed light on the two questions of interest. To our best knowledge, the use of goods-level data to address these questions in US-China trade is new to the literature.

Aside from studying the specifics of the China-US trade, China's abandonment of the hard peg also offers us an opportunity to study trade pricing behavior more generally. Indeed, under a free floating exchange rate, the exchange rate and firms' pricing behavior are endogenously determined, making it difficult to pin down causal relationships between the exchange rate and the pricing behavior of firms. For instance, the choice of pricing currency determines the degree of short-run ERPT, while Gopinath, Itskhoki, and Rigobon (2010) find evidence that desired level of ERPT determines the choice of invoicing currency, as firms that prefer low ERPT choose local currency pricing whereas firms that prefer high ERPT will set prices in their own currency. China's abandonment of the hard peg is largely an exogenous event for trade firms and provides a great case study to observe pricing behavior as the exchange regime changes.

In addressing our first question, we document changes in pricing behavior using goods-level price data and show that a simple open-economy menu cost model calibrated to data can replicate the important empirical observations. ${ }^{2}$ This aspect of our work complements existing theoretical studies that find that different price-

\footnotetext{
${ }^{1}$ For instance, see Timothy Geithner's remarks made at his public confirmation hearing by the US Senate Finance Committee on January 21, 2009.

${ }^{2}$ Several recent studies examine exporting firms' pricing behavior and ERPT using data from the same BLS goods-level price data. Some examples include Bils and Klenow (2004), Gopinath and Rigobon (2008), Klenow and Kryvtsov (2008), Nakamura and Steinsson (2008), Gopinath, Itskhoki, and Rigobon (2010), Gopinath and Itskhoki (2010), Neiman (2010), Nakamura and Steinsson (2012), and Bhattarai and Schoenle (2012), among others. Schoenle (2010) examines how firm's pricing behavior
} 
setting models can have strikingly different macroeconomic implications. ${ }^{3}$ In order to differentiate these theoretical models and to provide empirical guidance on future studies, the literature has placed significant emphasis on using goods-level price data to study price-setting behavior, especially after statistical agencies in the US, Europe, and other countries began allowing researchers to access their unpublished goods-level price data. ${ }^{4}$ For instance, Nakamura and Steinsson (2008) document that the frequency of price increases is positively correlated with US CPI inflation, while the frequency of price decreases is not. Gagnon (2009) finds from Mexican store-level prices that the relationship between aggregate inflation and price stickiness is different in high and low inflation regimes. ${ }^{5}$ These studies show that the pricing behavior of firms can change during periods of inflation, for instance, or when other fluctuations occur in the economy. While these findings are not consistent with time dependent sticky-price models that take price stickiness as exogenous and constant, they can be replicated in a state-dependent model - such as a menu cost model. The menu cost model in this paper achieves predictive abilities along the same lines, but we focus squarely on the effects of a change in the exchange rate regime.

Specifically, we first examine the following features of the data: price stickiness, the size of price changes, the fraction of price increases as opposed to decreases, and invoicing currency. As in Nakamura and Steinsson (2012), a large fraction of goods in our dataset never change their prices: a little over a quarter of US export prices to China and $40 \%$ of import prices from China never changed. This may be because price changes for some goods take the form of product replacement instead of regular price changes (a reason also given by Nakamura and Steinsson (2012)). Since the inclusion of these goods over-estimates price stickiness, we restrict our dataset to only those goods that have at least one price change. ${ }^{6}$ Even conditional on goods that have at least one price change, we document significant price stickiness in US-China trade prices - the median price duration of US export to China is 8.5 months over the entire sample period (10.5 months for US imports from China). Importantly, stickiness changes over time: applying the structural break tests of Bai and Perron (2003) on price duration, a break is detected around the abandonment of the hard peg in June 2005, when median price duration of US exports to China declines from from 9.5 months to 6.5 months (the decline is from 11.4 months to 9.2 months for US imports from China). Price stickiness also declines at

differs across domestic and export market. These empirical studies, like ours, provide valuable micro-foundations for modeling price-setting behavior of importers and exporters.

${ }^{3}$ For instance, Golosov and Lucas (2007) show that monetary shocks are almost neutral in a menu cost model, but they have significant real effects in a time-dependent pricing model. Betts and Devereux (2000) and Devereux and Engel (2003) emphasize that the choice of invoicing currency in international trade transactions critically determines the short-run ERPT and the optimal exchange rate policy in sticky-price open macroeconomic models.

${ }^{4}$ See Alvarez et al. (2006) and Dias et al. (2007) for examples using European data and Gagnon (2009) for Mexican data.

${ }^{5}$ Gagnon (2009) documents that when the inflation rate is low, the frequency of price changes is barely correlated with inflation. In contrast, when inflation rises above $10-15 \%$, the frequency and magnitude of price changes are strongly correlated with the inflation rate.

${ }^{6}$ Goods with no price change have a frequency of zero and a duration of infinity. 
sectoral levels, indicating that the decrease is mostly not due to composition effects. In addition, the fraction of price changes that are price increases rises after June 2005 for both import and export prices. The size of price changes also increases for US export prices to China in the post-June-2005 subsample.

Upon establishing the decline in price stickiness in data, we investigate whether a benchmark menu cost model in the style of Nakamura and Steinsson (2008) modified with a shock related to exchange rate movements has the ability to replicate the decrease of price stickiness after June 2005. We focus on replicating the decline in the stickiness of US export prices to China since the structural break there is more pronounced. In this model, each firm is subject to three shocks: an aggregate inflation shock, an aggregate demand shock related to exchange rate movements, and a firm-specific productivity shock. Given these shocks, the demand for its product, and the marginal cost, a firm chooses a price in dollars to maximize expected lifetime profit. ${ }^{7}$ The firm has to pay a real cost if it decides to change its price. We calibrate the model to match the extent of price stickiness, the fraction of price increases, and the size of price changes in the pre-June 2005 subsample. We then observe the consequences of replacing the parameters of the exogenous processes with estimates from the post-June 2005 data, while keeping other parameters constant.

We find that the model successfully replicates the decrease of price stickiness after June 2005, and can also partially explain the empirically observed increase in the fraction of price increases and the size of price changes. Exchange rate movements contribute significantly (about 60\%) to the decline of price stickiness in the data - as the RMB appreciates, aggregate demand for US exports increases, which induces US firms to change their prices. This finding complements previous papers that study the macroeconomic implications of the interaction between the exchange rate and price stickiness. For instance, in a menu cost model, Floden and Wilander (2006) study the ERPT and volatility of import prices when firms are subject to menu costs and adjust prices in response to exogenous exchange rate fluctuations, showing that firms update prices more frequently when the exchange rate is more volatile. Landry (2009) compares state-dependent and time-dependent pricing in a two-country dynamic model, and finds that a state-dependent pricing model matches aggregate data better than a time-dependent pricing because the nominal exchange rate and export demand influence price adjustment probabilities only in state-dependent pricing. ${ }^{8}$

Our second question of interest is the size of ERPT after the regime change, as measured by the percentage change in prices following a one percent change in the RMB. As previously discussed, the extent to which RMB appreciation is passed on to US import prices is important in light of China's huge current account surplus with the US. However, most empirical studies using aggregate price data find that ERPT into US

\footnotetext{
${ }^{7}$ Dollar pricing constitute the vast majority of cases in our data.

${ }^{8}$ Other examples of recent studies on open-economy models with menu costs include Midrigan (2007) and Landry (2010).
} 
import prices is usually low. ${ }^{9}$ Studies that specifically focus on the appreciation of the RMB usually also find that ERPT is small. For instance, Cui, Shu, and Chang (2009) find that ERPT to China's aggregate export price index is less than 50\%. Using sectoral level data, Auer (2012) finds that ERPT of RMB's appreciation from 2005 to 2008 into the US import price index is about $20 \% .{ }^{10}$

The fact that we use goods-level price data rather than aggregate prices distinguishes our paper from these studies. We previously pointed out that a large fraction of US imported goods from China never change prices during their lifetimes due to product replacement and other reasons (see, for instance, Nakamura and Steinsson (2012)), which can cause ERPTs estimated from aggregate price indexes to be severely downward biased. Indeed, Nakamura and Steinsson (2012) estimate that the product replacement bias can underestimate ERPT in the aggregate price index by nearly a factor of two. ${ }^{11}$ With this in mind, we estimate lifelong ERPT (Gopinath, Itskhoki, and Rigobon (2010)) using only goods that have at least one price change during June 2005 to July $2008,{ }^{12}$ in addition to the regression that includes all goods. The point estimate of lifelong ERPT that includes only goods with at least one price change is 0.88 , compared to 0.39 when all goods are included ( 0.39 is indeed close to previous studies that use aggregate price indices such as US import price index or China's export price index). This finding suggests that ERPTs estimated from price indexes substantially understate the effect of RMB appreciation on US-China trade prices. From a policy perspective, if US-China trade imbalances are caused by RMB undervaluation, our results suggest that RMB appreciation can be much more effective in balancing US-China trade than the literature has previously contemplated. However, if imbalances are caused by other structural factors rather than RMB undervaluation, as suggested by Song et al (2011), Wen (2011), and Ju, Shi, and Wei (2012) and other papers, RMB appreciation may substantially disrupt US-China trade through high ERPT without improving US-China trade imbalances.

The remainder of the paper is arranged as follows. Section 2 describes the import and export prices data used in this paper and reports some summary statistics. Section 3 presents the empirical facts on price rigidity, as well as the menu cost model used to explain these facts, and Section 4 reports the results of ERPT. Section 5 concludes and discusses directions for future research.

\footnotetext{
${ }^{9}$ For instance, Campa and Goldberg (2005) document that ERPT into the US import price index is less than $40 \%$ and has declined since the 1990s. Marazzi and Sheets (2007) find that ERPT to US import prices declined to only $20 \%$ after 2000. They argue that competition from China contributes to the decline of ERPT.

${ }^{10}$ Since imports from China account for only $22 \%$ in US total imports, Auer (2012) argues that actual ERPT of US imports from China could be very large.

${ }^{11}$ Gagnon, Mandel, and Vigfusson (2012) argue that the downward bias on ERPT due to selective entry and exit in the BLS's sampling method is modest over the first two years. However, the selective entry bias may not fully capture all product replacement bias discussed in Nakamura and Steinsson (2012).

${ }^{12}$ We choose the above sample period because China started to appreciate its currency in June 2005, but re-pegged to the dollar in July 2008 when the global financial crisis started.
} 


\section{Data Description}

To our best knowledge, our paper is the first to focus on the subset of data collected by the International Price Program (IPP) of the BLS pertaining to US-China trade prices. Our sample includes monthly import and export prices from the IPP Research Database (Blackburn, Kim, and Ulics, 2012) for the period from September 1993 to March 2011. The IPP surveys a sample of US companies based on how much they import and/or export in a given year. These firms are asked to provide transaction prices for a given item on a monthly basis, which are used to produce a modified Laspeyres index of import and export prices. Sampling occurs at the elementary level item (ELI) level, which in most cases corresponds to a 10-digit Harmonized System (HS) classification code.

The BLS currently selects establishments, ELIs, and individual goods using probability sampling techniques. Before the sampling process begins, the BLS obtains data from the Census Bureau or Customs Service on the value and frequency of imports or exports by US companies involved in trade. Such data are consolidated by company and by ELI within each company to decide from which company/ELI combination to sample. Next, the number of goods to request for each firm/ELI combination is determined based on a probability proportionate to size. Firms that import/export more from an ELI have a higher probability of being sampled for the prices of goods under that ELI. The last stage is to select goods within a given firm/ELI combination. The chance of an individual good being selected is proportionate to its share of trade within the firm/ELI combination. A more detailed description of the data and the collection process is provided by Gopinath and Rigobon (2008). ${ }^{13}$

The IPP dataset includes two types of prices: reported prices and net prices. Reported prices are those reported by importers/exporters on BLS survey forms. Reported prices can be either list prices, transaction prices, or estimated prices. Whenever possible, the BLS requests actual transaction prices. When transaction prices are not available or if a transaction does not take place in a particular period, firms are allowed to provide list prices (i.e,. sticker prices that sellers ask for) or estimated prices.

Reported prices are adjusted for discounts, duties, freight charges, or exchange rates, when applicable, to obtain net prices. Such adjustments are done by the BLS to reflect actual transaction prices as much as possible. Net prices are then used by the BLS to calculate import and export price indexes. Although net prices may better reflect the market prices, it can also potentially introduce spurious price changes by firms. For instance, the adjustment of the prices for exchange rate changes by the BLS will show price changes even if firms do not change their prices. To avoid this problem, we construct a series of net prices where

\footnotetext{
${ }^{13}$ Examples of other studies using the dataset include Clausing (2001), Gopinath and Rigobon (2008), Gopinath, Itskhoki, and Rigobon (2010), Gopinath and Itskhoki (2010), Berger et al. (2009), Nakamura and Steinsson (2012), and Neiman (2010).
} 
prices imputed by the BLS are excluded (labeled as net prices exclusive thereafter). We use both reported prices and net prices exclusive in our study.

In addition, we exclude intra-firm prices from our data following Gopinath, Itskhoki, and Rigobon (2010) and Nakamura and Steinsson (2010). Neiman (2010) finds that intra-firm prices are characterized by less stickiness, less synchronization, and greater exchange rate pass-through. These characteristics may just reflect the transfer pricing strategy used to minimize tax payment of multinational firms. Figure 1 shows the share of intra-firm prices for US imports from China. The share remains below $20 \%$ for most of our sample period, though it increases steadily over time. In contrast, currently about $48 \%$ of the prices for US total imports are intra-firm. This difference could result from China's restrictions on FDI, or it may also be that firms are endogenously choosing arm's length trade based on the types of goods that China exports.

Another data issue that must be addressed is missing values, which is common in studies using micro price data. We pull forward the last observation to close the gap between observations in our sample, following the standard treatment in the literature. ${ }^{14}$

Lastly, we exclude services and petroleum from our dataset. Various services indexes have been introduced and discontinued at different points during our sample period. Currently, the BLS produces only air freight and air passenger services indexes. Indexes for petroleum and ocean tanker freight are two examples that use weighted average prices (BLS, 1997). Moreover, due to the lagged nature of the weights, the volatility in the trade of petroleum can have a large (and possibly misleading) effect on the movement of price indexes.

\subsection{Share of Prices from China}

Figure 2 shows the share of import prices from China in total US imports at sectoral levels. The total share increased substantially from less than $10 \%$ to more than $35 \%$ over the past 20 years. Under the BLS's probability sampling methods, the higher the value or frequency of trade for a good, the more likely that good is included in the sample. Thus, the increasing share of import prices from China in total US imports reflects the sharp rise in US-China trade. The increase in the number of goods in our sample also suggests that China began exporting goods that it had not exported or had exported only minimally before.

The number of varieties of traded goods is commonly referred to as the extensive margin in the international trade literature. Recent research has focused on the role of the extensive margin in driving trade patterns. For instance, Yi (2003) uses the extensive margin to explain the growth in global trade following trade liberation. Ruhl (2008) argues that the extensive margin is important to understand high trade elas-

\footnotetext{
${ }^{14}$ For instance, see Nakamura and Steinsson (2012) and Gagnon, Mandel, and Vifugsson (2012). About 25\% of our sample are missing values, and are filled by pulling the last observation forward.
} 
ticities following a permanent shock. Naknoi (2008) shows that the extensive margin may also help explain real exchange rate volatility in macroeconomic models. Kehoe and Ruhl (2009) investigate the extensive margin using disaggregated (four-digit SITC code) trade data. They find significant evidence of growth in the extensive margin following a decrease of trade barriers. In particular, they document that China's WTO membership in 2001 had a large effect on the extensive margin for US-China trade. Our findings are consistent with Kehoe and Ruhl (2009), but we show that the effect on the extensive margin is strong even at more disaggregated levels; in Figure 2, the share of imports from China exhibits a sharp increase after 2001 in most sectors. Similar results exist at more disaggregated levels, such as the HS 10-digit level.

Figure 3 displays the share of price quotes in countries that have a declining share of prices in the BLS survey. These countries are mostly East Asian countries and Germany. The decline in the share of imported goods from East Asian countries reflects increasing vertical specialization in international trade among these countries and China. In the last two decades, China has become the hub of assembling final products for international trade due to its low labor costs.

In contrast, exports to China only account for a very small fraction of total US export prices in the IPP survey, though the share has increased over time in our sample. At its peak, the share of export prices to China in total US export prices is less than $4 \%$. This contrasts sharply with the import price data, where US import prices from China account for more than $35 \%$ of total import prices.

\subsection{Product Duration and Price Changes}

Table 1 reports summary statistics on the duration of goods and prices in of our dataset. For reported prices of US imports from China, 336,037 price quotes are reported for 14,547 goods. On average, a good lasts for 23.6 months before it is discontinued or replaced by a new product. This is much shorter than the mean life of a good in US total imports, which is 37.5 months as reported in Gopinath and Rigobon (2008). There is substantial heterogeneity in duration across goods: some goods exist for only one month, while the longest duration is as long as 125 months, or 10 years and 5 months. There is also substantial heterogeneity in the number of price changes across goods. The average number of price changes for each good is 1.7. A large share of goods (about 42\%) never change prices during their lifetime, while some goods have more than 50 price changes. Net prices that exclude imputed prices by the BLS behave similarly to reported prices in the above statistics.

The same summary statistics are also reported for US exports to China in Table 1. Much fewer goods and prices are recorded for US exports to China. In total, 24,261 reported prices are included for 1,048 goods. 
About $29 \%$ of prices never changed, which is smaller than that for US imports from China. On average, each good lasts for 24.2 months, similar to US import prices from China. US export prices on average have 5.1 price changes, which is more than double that for import prices from China. Since the average duration of goods is about the same for US imports from and exports to China, more price changes indicate that US exporters change their prices more frequently than their counterparts in China. Statistics for net prices exclusive of imputed prices are similar.

\subsection{Invoicing Currency}

The choice of invoicing currency plays an important role in international macroeconomic issues. For instance, when prices are sticky and set in the producer's currency (producer currency pricing or PCP), all short-run exchange rate changes will be passed on to the importing country's prices (100\% ERPT). In contrast, when prices are set in the importer's currency (local currency pricing, or LCP), the short-run ERPT is zero. Devereux and Engel (2003) find that the optimal exchange rate policy is different under PCP and LCP. Engel (2011) emphasizes the importance for the monetary policy to target currency misalignments under LCP.

In our sample, more than $97 \%$ of US import prices from China and almost $100 \%$ of US export prices to China are in the US dollar. This is consistent with Gopinath and Rigobon's (2008) finding that more than $90 \%$ of US imported goods are priced in dollars. Figure 4 shows the percent of non-dollar prices in US imports from China. Non-US-dollar currencies that are used to price Chinese imports include the Japanese yen, Taiwanese dollar, Hong Kong dollar, the RMB, and the Euro. ${ }^{15}$ Before 2004, most non-dollar transactions of US imports from China are in Hong Kong dollars. Since then, the share of the Hong Kong dollar has declined substantially. While the RMB is used as an invoicing currency after 2006, it only accounts for less than $0.2 \%$ of all prices.

For US exports to China, the US dollar was the only invoicing currency until 2009. After 2009, the Euro started to be used as an invoicing currency for US exports to China. However, the use of the Euro remains low: only about $1 \%$ of US export prices to China are priced in the Euro. Although China switched from the fixed exchange rate regime in June 2005 to a managed float, it seems that the regime switching has not affected the choice of invoicing currency by exporters - the US dollar still dominates as an invoicing currency in the trade between the US and China.

\footnotetext{
${ }^{15}$ The currency index is the major non-dollar currency that is used as invoicing currency. In this case, the good is priced based on a basket of currencies which are not disclosed to the BLS.
} 


\section{Price Stickiness}

In this section, we report results on the stickiness of US-China trade prices, focusing on reported prices. Following the literature, we use the frequency of price changes and frequency-implied durations to measure price stickiness. For each good, the frequency is defined as the number of price changes divided by the total number of price quotes. We then calculate the mean and median frequencies of price changes across all goods. The frequency-implied duration is calculated as in Nakamura and Steinsson (2008):

$$
d=-\frac{1}{\ln (1-f)}
$$

where $d$ is the duration and $f$ is the frequency of price changes. Table 2 reports our results. The median frequency of price changes for US exports to China is $5.9 \%$, which implies a duration of 16.5 months in our monthly data. Goods with zero price changes, of which there are many in our dataset, also have a frequency of zero, implying a duration of infinity. Since the inclusion of these goods overstates the price duration, we also calculate the frequency and duration conditional on a price change (i.e., for goods that have at least one price change). Even in this case, significant price rigidity remains: the median frequency is $11.1 \%$, implying a duration of 8.5 months.

There is significant heterogeneity of price stickiness across goods. Some products change prices much more often than others. As a result, the mean frequency is higher than the median frequency. The mean frequency of price changes for US exports to China is $14.1 \%$, implying a duration of 6.6 months.

The median fraction of price changes that are price increases is $62.5 \%$. This finding is similar to Nakamura and Steinsson's (2008) finding that about two thirds of changes in US consumer prices are price increases. The mean fraction of price increases is slightly smaller at $59 \%$.

Figure 5 presents the distribution of nonzero price changes for US exports to China. The distribution of price changes is very dispersed as there are both very small and very large price changes, similar to the pattern reported in Midrigan (2011) using scanner price data in retail stores. ${ }^{16}$ When looking at the average absolute size of price changes for each good, we find that the median size of price changes is $8.5 \%$ and the mean is $15.4 \%$ (see Table 2). These statistics also point to substantial heterogeneity price changes across goods.

The distribution of price changes for US imports from China has a similar pattern, but the size of price

\footnotetext{
${ }^{16}$ Midrigan (2011) extends the standard menu cost model to match the distribution of price changes and the existence of sales in price changes. He finds that after taking into account this additional set of micro price facts, the model generates a much larger real effect of monetary shocks than that in Golosov and Lucas (2007). Other important contributions to the second generation of state-dependent sticky-price models include Burstein and Hellwig (2007), Gertler and Leahy (2008), Costain and Nakov (2011), and Dotsey, King, and Wolman (2011), among others.
} 
changes are typically smaller for US import prices than export prices. The median size of price changes is $7.9 \%$ and the mean is $12.2 \%$. With regards to price stickiness, US imports from China exhibit higher price stickiness than US exports to China, as the median frequency-implied duration is 22.1 months for all imported Chinese goods and 10.5 months if we focus on goods with at least one price change. The mean duration is much smaller than the median: 12.6 months for all goods and 7.5 months conditional on a price change. The mean and median fraction of price changes that are price increases are about the same at $55 \%$.

Next, we split our sample into two subsamples: pre- and post-June-2005, to determine if price stickiness has changed after China switches the exchange rate regime. As shown in Table 2, conditional on a price change, the median price duration of US exports to China is 8.9 months in the pre-June-2005 subsample, but decreases to 6.5 months in the post-June-2005 subsample for goods with at least one price change. For all goods, the median fraction of price increases is $50 \%$ in the pre-June-2005 subsample, but rises to $66.7 \%$ post-June-2005. The median size of price changes also increases from $7.3 \%$ to $8.6 \%$.

Similar results hold for US import prices from China. The price duration declines and the fraction of price increases after June 2005. However, the size of price changes is very small between the two subsamples, which we also find for US export prices to China.

The calculation of price change frequency in the time series (i.e., for each month) may suffer from truncation bias as there are only 68 months in the post-June-2005 subsample. To address this problem, we follow Gagnon, Mandel, and Vigfusson (2012) and calculate the fraction of price changes in each month as a measure of frequency instead:

$$
\text { fraction change } t_{t}=\frac{\text { change }_{t}}{\text { change }_{t}+\text { no change }_{t}}
$$

where change ${ }_{t}$ is the number of prices in month $t$ that are different from their levels at month $t-1$ and no change $t_{t}$ is the number of prices that do not change from $t-1$ to $t$. The above equation calculates the share of price changes in the total number of prices in each month.

Figure 6 presents the percentage of price changes for US trade with China for each month. An increase in the percentage of prices changes indicates an decrease in price stickiness. Figure 6(a) shows that price stickiness decrease substantially after 2005 for US exports to China, a similar decline in price stickiness also occurs around 2005 for US imports from China as shown in Figure 6(b). 


\subsection{Structural Break Tests}

To more formally establish the change in price stickiness over time, we perform structural break tests based on Bai and Perron (2003) to identify the date and number of breaks for fraction change $e_{t}$. Two specifications are considered in our tests. In the first specification,

$$
\text { fraction change } e_{t}=a_{j}+\varepsilon_{t}
$$

for $t=T_{j-1}+1, \ldots, T_{j}$ and $j=1,2, \ldots, m+1 . m$ is the number of breaks and $T_{j}$ is the date of the $j^{t h}$ structural break, both are unknown and are estimated from the data. In each regime, fraction change ${ }_{t}$ has a different

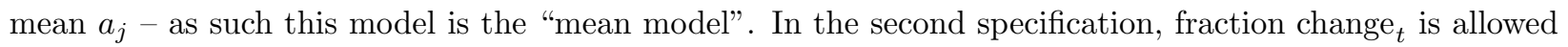
to have a different mean and a different deterministic time trend:

$$
\text { fraction change } e_{t}=a_{j}+b_{j} \times \frac{t}{T}+\varepsilon_{t}
$$

This specification is the "trend model"". ${ }^{17}$

Four tests are used to determine the number of breaks in each model:

1. Test $H_{0}: m=0$ against $H_{A}: m>0$;

2. Test $H_{0}: m=0$ against $H_{A}: m=k$ for pre-specified $k$;

3. Test $H_{0}: m=k$ against $H_{A}: m=k+1$ sequentially for $k=0,1, \ldots$, known as the "sequential test";

4. Bayesian Information Criterion (BIC).

The first test is used to test the null hypothesis of no break against the alternative that there is at least one break. In the second test, we test the null of no break against the alternative of $k$ breaks for $k=1, \ldots, 5$. We use the third test to find the number of breaks $k$ by testing the null of $k$ breaks against the alternative of $k+1$ breaks. The test is conducted sequentially for $k=0,1, \ldots$ until we fail to reject the null hypothesis. The BIC is also used to select the number of breaks.

\subsubsection{US Exports to China}

For the mean model,

1. The null of no breaks $\left(H_{0}: m=0\right)$ is strongly rejected;

\footnotetext{
${ }^{17}$ Deterministic time in (2) is expressed as the fraction $\frac{t}{T}$ purely due to technical reasons documented in Bai and Perron (2003).
} 
2. The null of no breaks $\left(H_{0}: m=0\right)$ is rejected in favor of the alternative of $1,2,3,4$, or 5 breaks;

3. The null of $H_{0}: m=k$ is rejected in favor of the alternative of $H_{A}: m=k+1$ for $k=1$, but we fail to reject the null for $k=2$.

4. BIC suggests that there is one break, with the two breaks model being the second best model.

All tests strongly reject the null of no breaks. Tests 3 and 4 suggest that there are two structural breaks (three regimes) in the data. The mean model indicates that the break dates are November 2002 and December 2005. The latter date is close to the date when the RMB began to appreciate. Table 3 presents the results of the structural break tests. The coefficients $a_{j}$ suggest that on average, $17.7 \%$ of prices change in each month in the first regime, $14.9 \%$ in the second and $22.3 \%$ in the third.

For the trend model, on the other hand, both the BIC and the sequential tests suggest that there is only one break, which is estimated to be November 2005. The share of price changes has a downward slope $(-0.040)$ in the first regime, indicating an increase in price stickiness through the mid 2000s. However, the price rigidity decreased substantially in the second regime with a slope of 0.093 .

From the structural break tests, the evidence of regime switching is very strong, as US export prices to China clearly become less sticky after 2005. Clearly, this is due to a change in China's exchange rate regime: when firms face more exchange rate fluctuations that drive their prices out of the optimal price, they change their prices more frequently to align their prices with the optimal one. A competing explanation could be that there is a composition effect: the US exports more products after 2005 in sectors with less sticky prices.

To discern which explanation holds in our data, we check the extent of price stickiness at disaggregated levels. Table 4 reports the sectoral level median price duration of US exports to China. The sectors are aggregations at the two-digit level HS codes. First, significant heterogeneity exists across sectors. The price duration varies from about two months in the sector of Animals and Vegetable Products to more than 12 months in several sectors such as Machinery/Electrical. In addition, the post-June-2005 sample has shorter durations than the pre-June-2005 sample in most sectors ( 8 out of 12 ), indicating a decline in price stickiness

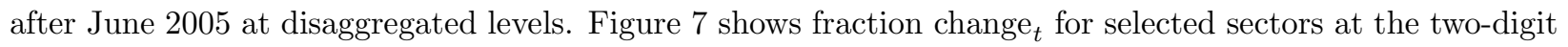
HS level, and declines in price stickiness around 2005 is also evident. These findings in disaggregated data suggest that the decline in price stickiness of US exports to China after 2005 is unlikely to be mainly driven by composition effects.

\subsubsection{US Imports from China}

For the mean model, 
1. The null of no breaks $\left(H_{0}: m=0\right)$ is strongly rejected;

2. The null of no breaks $\left(H_{0}: m=0\right)$ is rejected in favor of the alternative of $1,2,3,4$, or 5 breaks;

3. The null of $H_{0}: m=k$ is rejected in favor of the alternative of $H_{A}: m=k+1$ for $k=0,1$, but we fail to reject the null for $k=2$.

4. BIC suggests that there are two breaks.

Tests 1 and 2 strongly reject the null of no breaks. Test 3 suggests that there are two breaks (three regimes) in the data, as does the BIC test. The break dates selected by the mean model are May 1999 and April 2007 , which is close to the China's entry into the WTO, and the beginning of the financial crisis, respectively.

In contrast, both the sequential test and the BIC applied to trend model show that there is only one break on October 2005. Looking at fraction change ${ }_{t}$ for US imports from China time series, the difference between the mean and trend models may be driven by the fact that the mean model is an inadequately fits the data when trends clearly exist. The trend model suggests that prior to the break, the slope is -0.040 , meaning that price stickiness was increasing ${ }^{18}$, while the trend reverts to 0.098 after the break. These results are reported in the lower panel of Table 3 .

Similar to US exports to China, we also find that the decrease in price stickiness after 2005 for US imports from China is not driven by composition effects. ${ }^{19}$ Figure 8 shows fraction change ${ }_{t}$ in different sectors. We

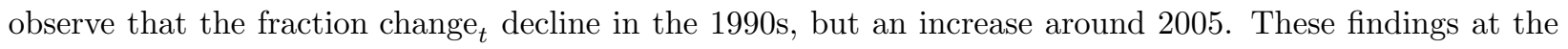
sectoral level suggest that the decline in price stickiness of US import prices from China after June 2005 are more likely due to changes in the macroeconomic environment. Although Gopinath and Rigobon (2008) find that price rigidity does not change following big exchange rate movements, it is possible that the exchange rate regime switch we are interested in has a much bigger impact on the pricing behavior of firms.

\subsection{Menu Cost Model}

The documented changes in trade price stickiness are not consistent with time-dependent stickiness price models (e.g., Calvo model), in which price stickiness is assumed to be constant and exogenous. Several recent studies find that a menu cost model can successfully replicate the correlation between price stickiness and aggregate inflation, providing support to state-dependent sticky-price models. We extend the simple menu cost model in Nakamura and Steinsson (2008) to a case of international trade and examine whether it can

\footnotetext{
${ }^{18}$ This is consistent with Gopinath and Rigobon's (2008) finding that price stickiness of overall US imports has increased from 1994 to 2005.

${ }^{19}$ Gopinath and Rigobon (2008) document that the increase in US import price rigidity from 1994 to 2005 is mainly due to the increase of price stickiness at disaggregated levels rather than the composition or country effects.
} 
replicate the decrease in price stickiness for US exports to China after 2005. Our findings provide further support for the menu cost model, but through the channel of exchange rate movements. We do not consider US import prices from China because the structural break tests suggest that changes price stickiness may also be driven by other factors such as China's accession to the WTO, as suggested by the structural break tests, which our simple menu cost model does not capture.

The menu cost model is first calibrated to match some micro price features of US exports to China (e.g., price stickiness) in the pre-June-2005 subsample. Then we replace the calibration of exogenous shocks with estimates from the post-June-2005 subsample, while keeping all other parameters constant, and observe variables of interest.

Suppose China is the home country and its demand for total imported goods is a CES function of imports from the US and the rest of the world (ROW):

$$
C_{M, t}=\frac{C_{R O W, t}^{\alpha} C_{U S, t}^{1-\alpha}}{\alpha^{\alpha}(1-\alpha)^{1-\alpha}}
$$

where $C_{M, t}$ is China's total import demand and $C_{U S, t}$ and $C_{R O W, t}$ are demands for imports from the US and ROW, respectively. Chinese demand for US imports is therefore:

$$
C_{U S, t}=(1-\alpha)\left(\frac{S_{t} P_{U S, t}}{P_{R O W, t}}\right)^{-\alpha} C_{M, t}
$$

where $S_{t}$ is the nominal exchange rate (yuan per dollar), $P_{U S, t}$ is the US-dollar price index of US exports to China, and $P_{R O W, t}$ is the price index of China's imports from the ROW (in RMB). Note that we use the US dollar for US export prices to China (producer currency pricing or PCP), which is consistent with exporters' behavior in data.

Assume that the US-goods composite is a CES aggregate of differentiated US goods with the elasticity of $\operatorname{substitution} \theta$. The demand for $\operatorname{good} z$ is:

$$
C_{U S, t}(z)=\left(\frac{P_{U S, t}(z)}{P_{U S, t}}\right)^{-\theta} C_{U S, t}=\left(\frac{P_{U S, t}(z)}{P_{U S, t}}\right)^{-\theta}(1-\alpha)\left(\frac{S_{t} P_{U S, t}}{P_{R O W, t}}\right)^{-\alpha} C_{M, t}
$$

where exporting firms take the nominal exchange rate $S_{t}$, aggregate prices $P_{U S, t}$ and $P_{R O W, t}$ as exogenous processes. 
The production function for US exporting firm $z$ is linear in labor:

$$
y_{U S, t}(z)=A_{U S, t}(z) L_{U S, t}(z)
$$

where $A_{U S, t}(z)$ is firm-specific productivity and $L_{U S, t}(z)$ is labor input of firm $z$. Let $W_{U S, t}$ be the nominal wage in the US. It is straightforward to find that the marginal cost for firm $z$ is $\frac{W_{U S, t}}{A_{U S, t}(z)}$.

In each period, the firm can choose to pay a fixed cost of $k$ units of labor to change its price. Otherwise, it charges the same price as in the last period. Nominal profits of the firm are:

$$
\pi_{U S, t}(z)=\left\{\begin{array}{cc}
\left(P_{U S, t-1}(z)-\frac{W_{U S, t}}{A_{U S, t}(z)}\right) C_{U S, t}(z) & \text { if no price change } \\
\left(P_{U S, t}(z)-\frac{W_{U S, t}}{A_{U S, t}(z)}\right) C_{U S, t}(z)-W_{U S, t} k & \text { if change price }
\end{array}\right\}
$$

The real profit of firm $z$ is:

$$
\widehat{\pi}_{U S, t}(z)=\frac{\pi_{U S, t}(z)}{P_{U S, t}}=\left\{\begin{array}{c}
\left(\frac{\widehat{P}_{U S, t-1}(z)}{P_{U S, t} / P_{U S, t-1}}-\frac{\widehat{W}_{U s, t}}{A_{U S, t}(z)}\right) \widehat{P}_{U S, t}^{-\theta}(z)(1-\alpha) \tau_{t}^{-\alpha} C_{M, t} \quad \text { if no price change } \\
\left(\widehat{P}_{U S, t}(z)-\frac{\widehat{W}_{U S, t}}{A_{U S, t}(z)}\right) \widehat{P}_{U S, t}^{-\theta}(z)(1-\alpha) \tau_{t}^{-\alpha} C_{M, t}-\widehat{W}_{U S, t} k \quad \text { if change price }
\end{array}\right\},
$$

where $\tau_{t}=\frac{S_{t} P_{U S, t}}{P_{R O W, t}}$ and prices with a hat are the corresponding nominal prices divided by $P_{U S, t}$.

Following Nakamura and Steinsson (2008), we assume that the aggregate demand and real marginal cost are constant:

$$
\begin{aligned}
C_{M, t} & =C, \\
\widehat{W}_{U S, t} & =\frac{W_{U S, t}}{P_{U S, t}}=\frac{\theta-1}{\theta} .
\end{aligned}
$$

The logarithms of productivity, the price level, and $\tau_{t}$ are assumed to follow:

$$
\begin{aligned}
\log \left(A_{U S, t}(z)\right) & =\rho \log \left(A_{U S, t-1}(z)\right)+\varepsilon_{t}(z), \\
\log \left(P_{U S, t}\right) & =\mu+\log \left(P_{U S, t-1}\right)+\eta_{t}, \\
\log \left(\tau_{t}\right) & =\nu+\phi \log \left(\tau_{t-1}\right)+\varepsilon_{\tau, t},
\end{aligned}
$$

where $\varepsilon_{t}(z), \eta_{t}$, and $\varepsilon_{\tau, t}$ are iid with zero mean and standard deviations of $\sigma_{\varepsilon}, \sigma_{\eta}$, and $\sigma_{\tau}$, respectively.

Given exogenous processes, each firm chooses whether or not to change its price and determines the 
optimal price to maximize real profits in equation (8) if it chooses to change its price. This model is very similar to Nakamura and Steinsson's (2008), but while their model is one with a closed economy, ours adds the exogenous process $\tau_{t}$, which is related to the exchange rate. Indeed, if parameter $\alpha$ is set to zero, $\tau_{t}$ in equation (8) drops out and the model reduces to the one in Nakamura and Steinsson (2008).

To calibrate the data, we set $\alpha=0.93$, which matches the average share of the ROW in China's total imports from 1993 to 2011. Following Nakamura and Steinsson (2008), the discount factor is set equal to $\beta=0.96^{1 / 12}$ and $\theta$ is set to 4 . We calculate the US export price index to China from our dataset and estimate $\mu=1$ and $\sigma_{\eta}=0.009$ in the pre-June-2005 subsample.

We need a measure of $\tau$ to calibrate $\nu, \phi$ and $\sigma_{\tau}$. Unfortunately, China's import price index from the ROW $\left(P_{R O W, t}\right)$ is unavailable. A potential replacement option is China's aggregate import price index from all trading partners including the US. Since imports from the US only account for 7\% of China's total imports, the aggregate index may be a reasonable proxy to a ROW index. Because China's aggregate import price index is only available after 2005, we use China's producer price index (PPI) for all industries (available after January 1996) as a proxy for China's import price index. During overlapping periods of availability, the PPI for all industries appears to correlate highly with the import price index, with the import price index being more volatility than the PPI. We estimate $\nu=0.79, \phi=0.885$, and $\sigma_{\tau}=0.01$ in the pre-June-2005 subsample.

Similar to Nakamura and Steinsson (2008), we calibrate $\frac{K}{(1-\alpha) \tau^{-\alpha} C_{M}}, \rho$, and $\sigma_{\varepsilon}$ to match the share of price changes in each month, the share of price changes that are price increases, and the average size of the price changes. In the pre-June-2005 subsample (from January 1996 to June 2005), the median share of price changes in each month is $10.6 \%$, the share of price changes that are price increase is $50 \%$, and the median absolute size of price changes is $7.2 \%$. We choose $\frac{K}{(1-\alpha) \tau^{-\alpha} C_{M}}, \rho$, and $\sigma_{\varepsilon}$ to minimize the sum of percent deviations of our model from the targeted statistics, resulting in model values 10.6\%, 50\%, and 7.6\%, respectively, for the three shares.

Holding everything else constant, we next re-estimate the processes of $\log \left(P_{U S, t}\right)$ and $\log \left(\tau_{t}\right)$ with the post-June-2005 subsample. We feed the new estimates of these two processes into our model and examine how they change the share of price changes, and other statistics. We estimate that $\mu=1.002$ and $\sigma_{\eta}=0.019$. $\mu$ is higher in the second subperiod, indicating that US export prices to China $\left(P_{U S, t}\right)$ increase faster after June 2005. The standard deviation of the inflation $\left(\sigma_{\eta}\right)$ also increases from 0.009 to 0.019 . For the process of $\log \left(\tau_{t}\right)$, we estimate that $\nu=0.19, \phi=0.971$, and $\sigma_{\tau}=0.014$.

Table 5 presents the results of the menu cost model. We consider three models for the post-June2005 subsample with the first one as the benchmark model, where we keep everything else constant while 
replacing the processes of $\log \left(P_{U S, t}\right)$ and $\log \left(\tau_{t}\right)$ with estimates from the post-June-2005 data. The share of price changes increases from $10.6 \%$ to $15.9 \%$ in the model, which is quite close to the actual observed share of price changes in the post-June-2005 data. The share of price increases and the size of price changes also increase in the model after June 2005, but are smaller compared to the data. The menu cost model seems to match well the decrease in price rigidity post-June-2005.

Inflation of $P_{U S, t}, \mu$, is higher in the post-June-2005 subsample than in the pre-June-2005 subsample. Since Gagnon (2009) shows that high inflation in the menu cost model can reduce price stickiness, in the second model "Only $P_{U S, t}$ ", we examine the effect of the change in $\mu$ in driving our benchmark results. In this model, we only replace $\mu$ and $\sigma_{\eta}$ in the process of $\log \left(P_{U S, t}\right)$ with their estimates from the post-June2005 subsample while keeping all other parameters the same as in the pre-June-2005 subsample. We find that this inflation effect contributes to $54.7 \%$ of the increase in the share of price changes. ${ }^{20}$ This model also generates bigger increases in the share of price increases and the size of price changes compared to the benchmark model.

In the third model, "Only $\tau_{t}$ ", we investigate the effect of $\log \left(\tau_{t}\right)$. We only replace $\nu$ and $\sigma_{\tau}$ in the process of $\log \left(\tau_{t}\right)$ with their estimates from the post-June-2005 subsample while keeping all other parameters the same as in the pre-June-2005 subsample. The share of price changes increases from $10.6 \%$ to $12.9 \%$, which accounts for $43.4 \%$ of the increase in the share of price changes in the benchmark model. The fraction of price increases rises remains the same at $50 \%$. On the other hand, the size of price changes is $7.4 \%$, compared to $7.2 \%$ observed in the data.

Note that the share of price changes increases more than the sum of increases in models "Only $P_{U S, t}$ " and "Only $\tau_{t}$ ". This result indicates that the interaction between $\log \left(P_{U S, t}\right)$ and $\log \left(\tau_{t}\right)$ also contributes to the decrease of price stickiness, and the benchmark model captures this interaction.

\section{Exchange Rate Pass-through}

The size of the pass-through of the exchange rate into local currency import prices is critical for policy issues such as the international transmission of the inflation and the optimal exchange rate policy. This issue is of particular importance for Chinese products in light of China's large current account with the US.

\footnotetext{
${ }^{20}$ The "Only $P_{U S, t}$ " model shows an increase in the share of price changes from $10.6 \%$ to $13.5 \%$, which accounts for $54.7 \%$ of the $15.9 \%-10.6 \%=5.3 \%$ increase predicted by the benchmark model.
} 
The standard pass-through regression takes the form:

$$
\Delta p_{t}=\alpha+\gamma \Delta s_{t}+\delta \Delta c_{t}^{*}+\beta \Delta d_{t}+\varepsilon_{t},
$$

where $p_{t}$ is the $\log$ import price denominated in the importing country's currency at time $t, s_{t}$ is the $\log$ exchange rate, $c_{t}^{*}$ is the log production cost of exporters, and $d_{t}$ is the log import demand. ${ }^{21}$ The coefficient $\gamma$ measures the percentage change in the import price given a $1 \%$ change in the exchange rate. Pass-through is usually found incomplete $(\gamma<1)$ and has in general declined over the last two to three decades for US import prices.

Given the limitations of data, previous studies on the ERPT of US imports from China have used aggregate price indexes. However, Nakamura and Steinsson (2012) point out that an important caveat when estimating the exchange rate pass-through using aggregate price indexes: price adjustments may take the form of product replacement, and as such some US imports experience no price changes during their lifetime. Product replacement cannot be adequately measured in aggregate price indices because it is difficult to link a product with its replacement in practice, and including goods that are replaced in aggregate price indexes smooths the price indexes and results in a downward biased estimate of the ERPT.

As shown in the previous section, more than a third of US imported goods from China never change their prices. We estimate the ERPT of US imports from China using goods-level prices, allowing us to exclude prices that never change in our estimation of ERPT and investigate how much such prices may affect the estimate of ERPT. We estimate lifelong ERPT as in Gopinath, Itskhoki, and Rigobon (2010):

$$
\Delta p_{i}=\gamma \Delta s_{i}+\beta^{\prime} z_{i}+\varepsilon_{i}
$$

where $\Delta p_{i}$ is the change of the price of good $i$ during its life, $\Delta s_{i}$ is the change in the exchange rate over the same period, and $z_{i}$ includes corresponding changes in other control variables, which are the US CPI inflation rate, China's CPI inflation rate, and US GDP growth. Our sample begins in June 2005 when the RMB started to appreciate against the US dollar and ends in July 2008 as China temporarily halted RMB appreciation between starting July 2008 in response to the global financial crisis.

Table 6 presents the results of aggregate lifelong ERPT. In our estimation, each good is weighted by annual trade weight at the HS4 level. When all prices are included, ERPT is much smaller than one: 0.39 when reported prices are used and 0.48 when net prices exclusive are used. These numbers are within the

\footnotetext{
${ }^{21}$ Lags of $\Delta p_{t}$ or $\Delta s_{t}$ are usually included in the regression.
} 
range of ERPT estimated from aggregate price indexes. However, when we condition our estimate on goods that have at least one price change, the estimated ERPT increase by more than two times, at 0.88 to 1.02 for reported prices and net prices exclusive, respectively. Besides the product replacement bias as discussed in Nakamura and Steinsson (2012), the above increase in ERPT when focusing on goods with price changes may also be attributed to composition effects.

Gopinath and Itskhoki (2010) document that goods with frequent price adjustments also have high ERPT. In Table 6, we also estimate ERPT using goods with one or two price changes, and also goods with more than two price changes. As in Gopinath and Itskhoki (2010), US imports from China that change prices more frequently are found to have higher ERPT.

As we remove goods with no price changes, it is possible that goods with low ERPT and low frequency of price adjustment are deleted disproportionately from our sample, although the share of items with no price change is similar across most sectors at the two-digit HS level in our sample. This suggest that if the bias exists, it is likely not caused by the composition effects.

The variation of exporter's profit margin is usually believed to be an important contributor to the incomplete long-run ERPT into import prices. Since most of China's exports are labor-intensive products with low profit margins, however, it is unlikely that Chinese exporters can absorb more than half of the exchange rate appreciation by squeezing their profit margins. Our finding of high ERPT based on goodslevel data is more consistent with this conjecture, in contrast to the low ERPT estimated using aggregate price indices. Our estimates of ERPT is also consistent with those of Li, Ma, Xu, and Xiong (2010), who use firm-level data of 2000-2006 to study Chinese firms' export behavior and find that ERPT to China's export prices (in importing country's currency) is between 0.83 to 1 . Like ours, their results also suggest that Chinese exporting firms absorb only a small portion of exchange rate changes. ${ }^{22}$

Our estimates of high ERPT for US imports from China suggest that RMB appreciation could have a big impact on US-China trade prices. If the US-China trade imbalance is indeed caused by currency undervaluation, our results suggest that an exchange rate correction will have significant effects in improving the imbalance. In contrast, if the trade imbalance is caused by factors unrelated to nominal exchange rate such as technology and labor market dynamics, a RMB appreciation could be very disruptive, as it might cause unnecessary price adjustment without solving the structural issues that induce the trade imbalance. Therefore, the factors that contribute to the US-China trade imbalance deserves careful evaluation in the

\footnotetext{
${ }^{22}$ Our price data have several advantages compared to those in $\mathrm{Li}, \mathrm{Ma}, \mathrm{Xu}$, and Xiong (2010). Our goods-level actual price data are more accurate than their unit-value prices (export value divided by trade volume) that are at the eight-digit HS level. Their data are not suitable for estimating ERPT between the US and China either because the annual data ended in 2006, with only one observation after the RMB started to appreciate against the dollar.
} 
future by researchers and policymakers.

The finding that ERPT is high for US imports from China, which are almost always priced in the dollar, differs from the results found in Gopinath, Itskhoki, and Rigobon (2010) for a group of advanced economies. ${ }^{23}$ Even when they focus on goods with price changes, ERPT of imports that are priced in the dollar remains much lower than those priced in exporting countries' currencies. Their findings suggest that firms will choose the importing country's currency if they prefer low ERPT, while exporters that prefer high ERPT will set prices in their own currency. Our result leads one to question why Chinese firms use the dollar as invoicing currency even if their preferred ERPT is high. This could be because the RMB is not yet freely convertible due to China's capital control measures. It will be interesting to see if more Chinese imports are priced in the RMB as China relaxes its capital controls.

\section{Conclusion}

In this paper, we are interested in the behavior of firms in US-China trade in setting prices, and the degree to which exchange rate movements pass-through to prices. China's exchange rate regime switching in 2005 provides a great opportunity to study these issues, and allows us to shed light on broader modeling questions related to international price setting.

Theoretical models based on different assumptions about the pricing behavior of firms give rise to sharply different answers on important policy questions such as the impact of monetary shocks and the optimal monetary and exchange rate policies. Several recent studies investigate the pricing behavior of firms and their implications on theoretical models using goods-level price data collected by the BLS. Focusing on goodslevel data in US-China trade, we document several interesting findings. First, significant price rigidity exists in US-China trade even after we exclude prices that never change. The median price duration is 8.5 months for US exports to China and 9.4 months for US imports from China. Second, price rigidity substantially decreases after June 2005, when China abandoned it's hard peg to the US dollar. The frequency-implied duration declined more than $30 \%$ for US exports to China and $20 \%$ for US imports from China. Our benchmark menu cost model calibrated to data can replicate the decline of price rigidity, as the exchange rate regime changes. Third, lifetime ERPT into US import prices from China is quite small when aggregate price indices are used, but increases to close to complete when we focus on goods that have at least one price change. We were able to estimate this result because goods-level data allows us to filter out the goods that never change their prices. Our results support findings in Nakamura and Steinsson (2012) that product

\footnotetext{
${ }^{23}$ More than $97 \%$ of US imports from China are priced in the dollar.
} 
replacement may substantially underestimate ERPT in aggregate price data.

Our findings also raise several interesting issues for future research. First, Gopinath and Rigobon (2008) find that the price stickiness for US imports increased in the 1990s. They argue that the increase in price stickiness contributed to the decline of ERPT into US import prices. One interesting study would be to assess if price rigidity for goods from other countries has also increased in the last decade and the impact on ERPT.

Second, we find that ERPT for goods with at least one price change is quite large for US imports from China, even when the vast majority of these imports are priced in the dollar. This result contradicts the findings of Gopinath, Itskhoki, and Rigobon (2010) for a group of advanced economies, where firms usually choose home currency to price their products if high ERPT is preferred. It would be interesting to track whether more Chinese exports are priced in the RMB going forward.

Third, as in Midrigan (2011), we document that the distribution of price changes differs from that in the standard menu cost model. Midrigan (2011) shows that incorporating this empirical feature into the menu cost model can substantially increase the real effect of the monetary shock. For future research, we want to study the impact of incorporating the distribution of price changes into a trade model. 


\section{References}

[1] Auer, Raphael, 2012, "Exchange Rate Pass-through, Domestic Competition and Inflation-Evidence from the 2005/08 Revaluation of the Renminbi," CESIFO WORKING PAPER NO. 3759.

[2] Alvarez, Luis J., Emmanuel Dhyne, Marco M. Hoeberichts, Claudia Kwapil, Harve Le Bihan, Patrick Lunnemann, Fernando Martins, Roberto Sabbatini, Harald Stahl, Philip Vermeulen, and Jouko Vilmunen, 2006, "Sticky Prices in the Euro Area: A Summary of New Micro Evidence," Journal of the European Economic Association, 4: 575584.

[3] Bai, Jushan and Pierre Perron, 1998, "Estimating and Testing Linear Models with Multiple Structural Changes," Econometrica, 1998, vol 66, 47-78.

[4] Bai, Jushan and Pierre Perron, 2003, "Computation and Analysis of Multiple Structural Changes," Journal of Applied Econometrics, 18: 1-22.

[5] Bhattarai, Saroj and Raphael Schoenle, 2012 "Multiproduct Firms and Price-Setting: Theory and Evidence from U.S. Producer Prices," Working paper, Pennsylvania State University and Brandeis University.

[6] Berger, David, Jon Faust, John H. Rogers, and Kai Steverson, 2009, "Border Prices and Retail Prices," International Finance Discussion Papers, Number 972, Federal Reserve Board.

[7] Betts, Caroline and Michael Devereux, 2000, "Exchange Rate Dynamics in a Model of Pricing-toMarket," Journal of International Economics, 50(1): 215-44.

[8] Bils, Mark and Pete Klenow, 2004, "Some Evidence on the Importance of Sticky Prices," Journal of Political Economy, 112(5): 947-985.

[9] Blackburn, Taylor, Mina Kim, and Rozi Ulics, 2012, IPP Research Database, Bureau of Labor Statistics January 2012.

[10] BLS, 1997, BLS Handbook of Methods, Chapter 15, April 1997.

[11] Burstein, Ariel and Christian Hellwig, 2007, "Prices and Market Shares in a Menu Cost Model," manuscript September 2007.

[12] Campa, Jose Manuel and Linda S. Goldberg, 2005, "Exchange Rate Pass-Through into Import Prices, Review of Economics and Statistics, 87(4): 679-690. 
[13] Clausing, Kimberly, 2000, "The Behavior of Intrafirm Trade Prices in U.S. International Price Data," The US Bureau of Labor Statistics Working Paper 333.

[14] Costain, James and Anton Nakov 2011, "Distributional Dynamics under Smoothly State-Dependent Pricing," Journal of Monetary Economics, 58:646-665.

[15] Cui, Li, Chang Shu, and Jian Chang, 2009, "Exchange Rate Pass-through and Currency Invoicing in China's Exports," China Economic Issues, Hong Kong Monetary Authority, July 2009.

[16] Devereux, Michael and Charles Engel, 2003, "Monetary Policy in the Open Economy Revisited: Price Setting and Exchange-Rate Flexibility," Review of Economic Studies, 70(4): 765-83.

[17] Dias, Daniel A., Carlos Robalo Marques, and Joao M. Santo Silva, "Time or State Dependent Price Setting Rules? Evidence from Micro Data, European Economic Review, 51: 15891613.

[18] Dotsey, Michael, Robert G. King, and Alexander L. Wolman, 2011, "Inflation and Real Activity with firm-level Productivity Shocks," Manuscript.

[19] Engel, Charles, 2011, "Currency Misalignments and Optimal Monetary Policy: A Reexamination," American Economic Review, 101: 295-308.

[20] Floden, Martin and Fredrik Wilander, 2006, "State Dependent Pricing, Invoicing Currency, and Exchange Rate Pass-through, Journal of International Economics, 70: 178-196.

[21] Gagnon, Etienne, 2009, "Price Setting During Low and High Inflation: Evidence from Mexico," Quarterly Journal of Economics, Ausust 2009, 1221-1263.

[22] Gagnon, Etienne, Benjamin Mandel, and Robert Vigfusson, 2012, "Missing Import Price Changes and Low Exchange Rate Pass-Through," International Finance Discussion Papers, Number 1040r, Board of Governors of the Federal Reserve System.

[23] Gertler, Mark and John Leahy, 2008, "A Phillips Curve with an Ss Foundation," Journal of Political Economy, 116(3): 533-572.

[24] Golosov, Mikhail and Robert Lucas, 2007, "Menu Costs and Phillips Curves," Journal of Political Economy, 115(2): 171-199.

[25] Gopinath, Gita and Roberto Rigobon, 2008, "Stricky Borders," Quarterly Journal of Economics, May 2008, 531-575. 
[26] Gopinath, Gita and Oleg Itskhoki, 2010, "Frequency of Price Adjustment and Pass-Through," Quarterly Journal of Economics, May 2010, 675-727.

[27] Gopinath, Gita, Oleg Itskhoki, and Roberto Rigobon, 2010, "Currency Choice and Exchange Rate Pass-Through," American Economic Review, 100(1): 304-336.

[28] Groenewold, Nicolaas and Lei He, 2007, "The US-China Imbalance: Will the Revaluing RMB Help (Much)?" Economics Letters, 96, 127-132.

[29] Ju, Jiandong, Shi Kang, and Shangjin Wei, 2012, "Trade Reforms and Current Account Imbalances: When does the General Equilibrium Effect Overtuen a Partial Equilibrium Intuition?", NBER Working Paper 18653.

[30] Kehoe, Tim and Kim Ruhl, 2009, "How Important Is the New Goods Margin in International Trade?" Federal Reserve Bank of Minneapolis Research Department Staff Report 324.

[31] Klenow, Peter J., and Oleksiy Kryvtsov, "State-dependent or Time-dependent Pricing: Does It Matter for Recent U.S. Inflation? Quarterly Journal of Economics, 123: 863904.

[32] Landry, Anthony, 2009, "Expectations and Exchange Rate Dynamics: A State-dependent Pricing Approach, Journal of International Economics, 78: 60-71.

[33] Landry, Anthony, 2010, "State-dependent Pricing, Local-currency Pricing, and Exchange Rate Passthrough, Journal of Economic Dynamics and Control, 34: 1859-1871.

[34] Li, Hongbin, Hong Ma, Yuan Xu, and Yanyan Xiong, 2010, "How do Exchange Rate Movements Affect Chinese Exports? A Firm-level Investigation," Working Paper, Tsinghua University.

[35] Marazzi, Mario and Nathan Sheets, 2007, "Declining Exchange Rate Pass-through to U.S. Import Prices: The Potential Role of Global Factors," Journal of International Money and Finance, 26: 924-947.

[36] Midrigan, Virgiliu, 2007, "International Price Dispersion in State-dependent Pricing Models," Journal of Monetary Economics, 54: 2231-2250.

[37] Midrigan, Virgiliu, 2011, "Menu Costs, Multiproduct Firms, and Aggregate Fluctuations," Econometrica, 79(4): 1139-1180.

[38] Nakamura, Emi and Jon Steisson, 2008, "Five Facts About Prices: A Revaluation of Menu Cost Models," Quarterly Journal of Economics, November 2008, 1415-1464. 
[39] Nakamura, Emi and Jon Steisson, 2012, "Lost in Transit: Product Replacement Bias and Pricing to Market," American Economic Review, 102(7): 3277-3316.

[40] Naknoi, Kanda, 2008, "Real Exchange Rate Fluctuations, Endogenous Tradability and Exchange Rate Regimes," Journal of Monetary Economics 55(3): 645-663.

[41] Neiman, Brent, 2010, "Stickiness, Synchronization, and Passthrough in Intrafirm Trade Prices," Journal of Monetary Economics, 57: 295308.

[42] Schoenle, Raphael, 2010 "International Menu Costs and Price Dynamics," Working paper, Brandeis University.

[43] Shu, Chang, Xiaojing Su, and Nathan Chow, 2008, "Exchange Rate Pass-through in Mainland China," China Economic Issues, Hong Kong Monetary Authority, April 2008.

[44] Song, Zheng, Kjetil Storesletten, and Fabrizio Zilibotti, 2011, "Growing Like China," American Economic Review, 101(1): 196233.

[45] Wen, Yi, 2011, "Explaining Chinas Trade Imbalance Puzzle," Federal Reserve Bank of St. Louis Working Paper 2011-018A.

[46] Yi, Kei-Mu, 2003, "Can Vertical Specialization Explain the Growth of World Trade? Journal of Political Economy, 111 (1): 52-102. 
Figure 1: Share of Intra-firm Prices in US Imports from China

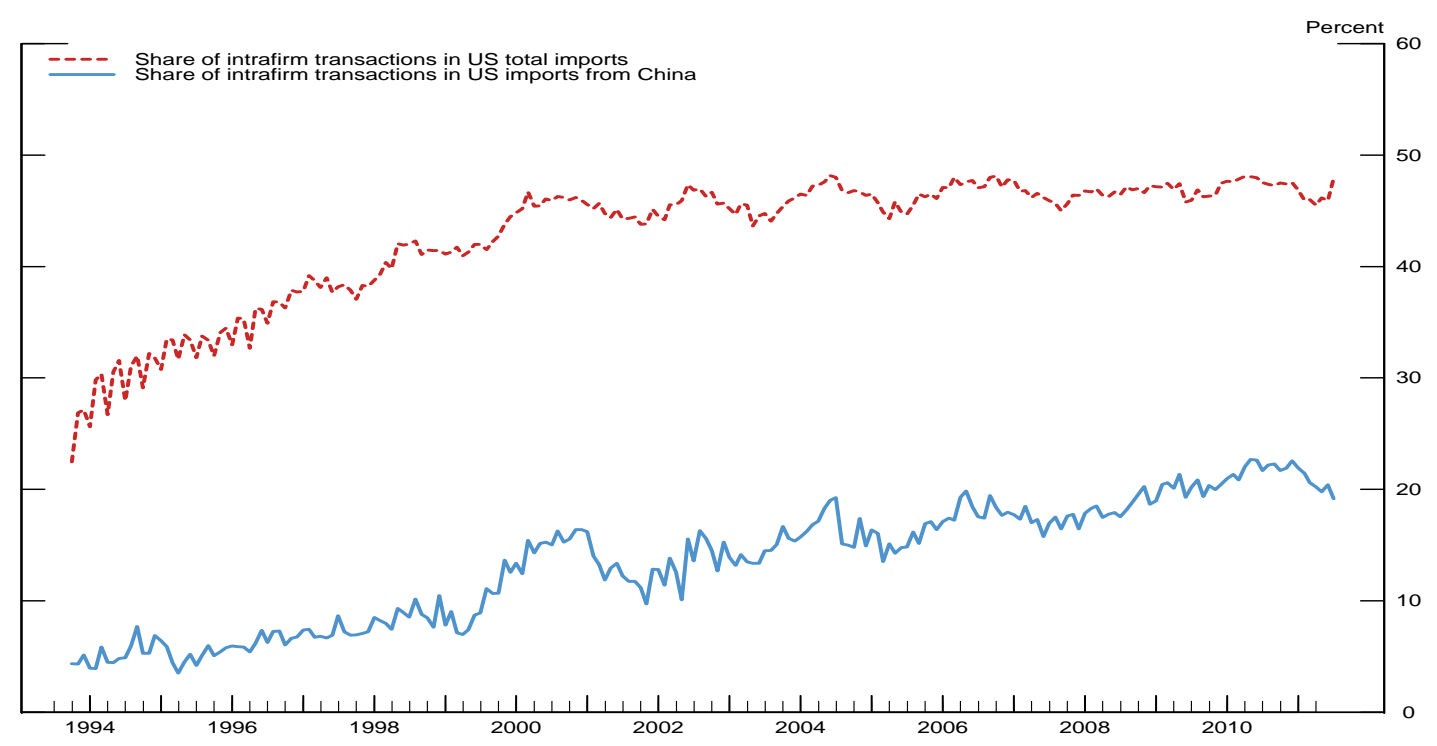

NOTE: shares are calculated from the raw data in the IPP database.

Figure 2: Share of Price Quotes from China in US Total Imports (Excluding Intra-firm Prices)

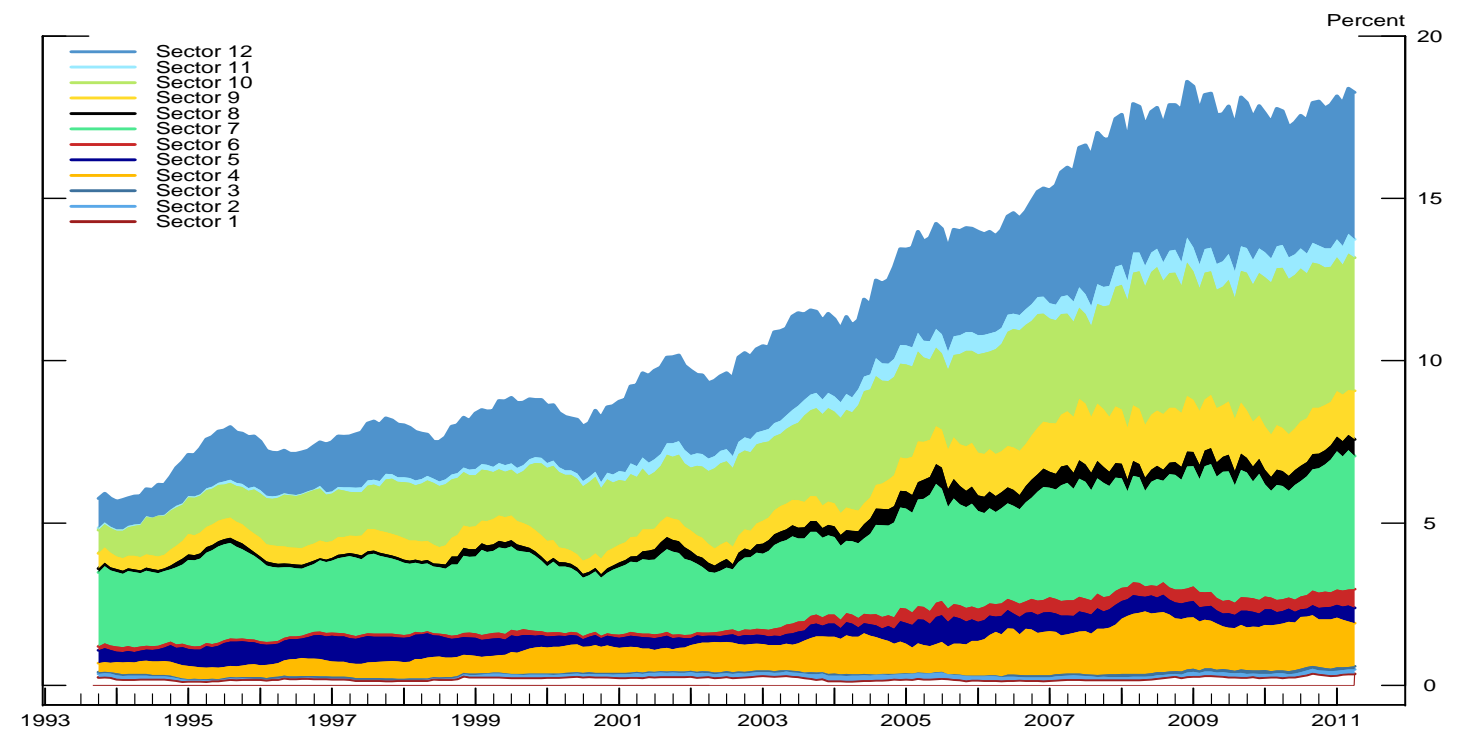

NOTE: shares are calculated from our constructed dataset based on reported prices. 
Figure 3: Share of Countries/Regions with a Declining Number of Prices

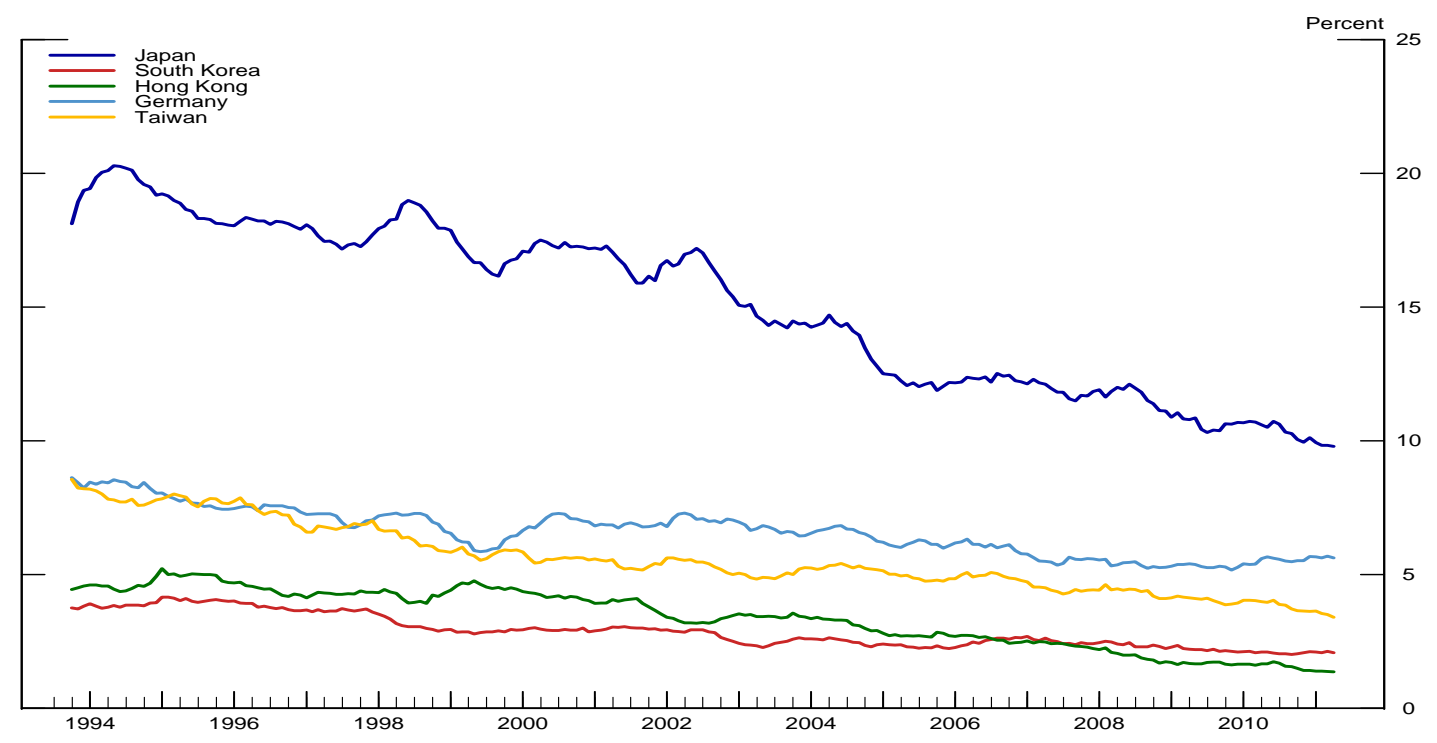

NoтE: shares are calculated from our constructed dataset based on reported prices.

Figure 4: Share of Non-dollar Transactions in US Imports from China

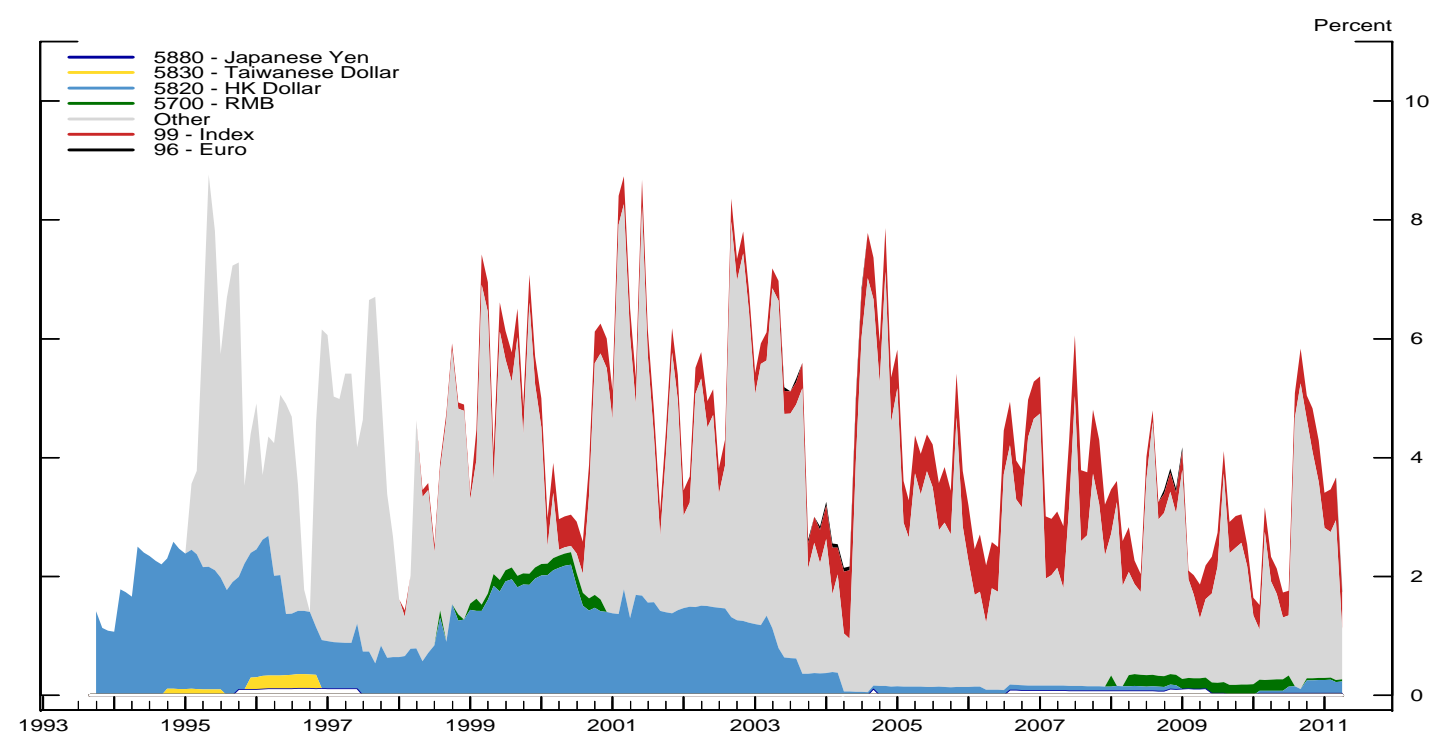

NOTE: $97 \%$ of imports are priced in the US dollar. Shares are calculated from our constructed dataset based on reported prices. 
Figure 5: Distribution of Non-zero Price Changes (US Exports to China)

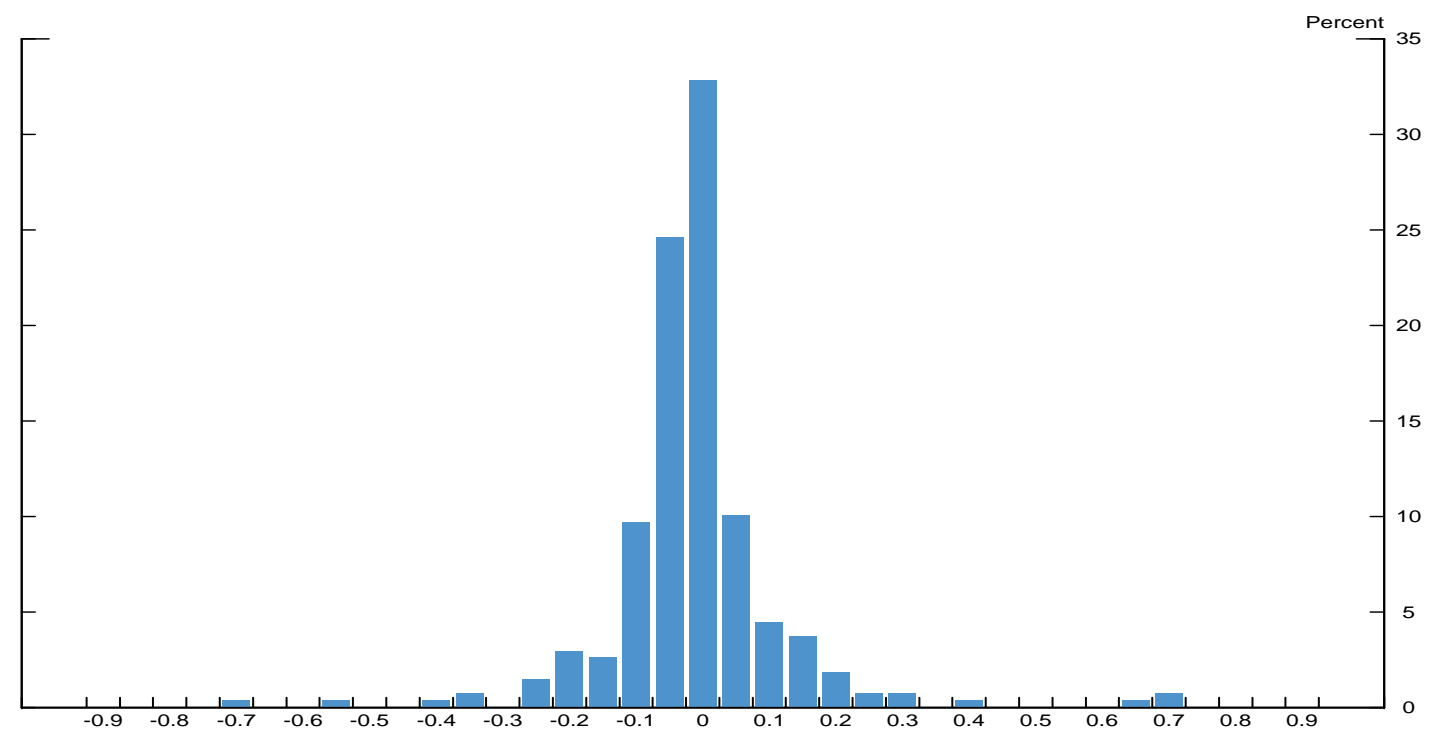

(a) Pre-June-2005 Subsample

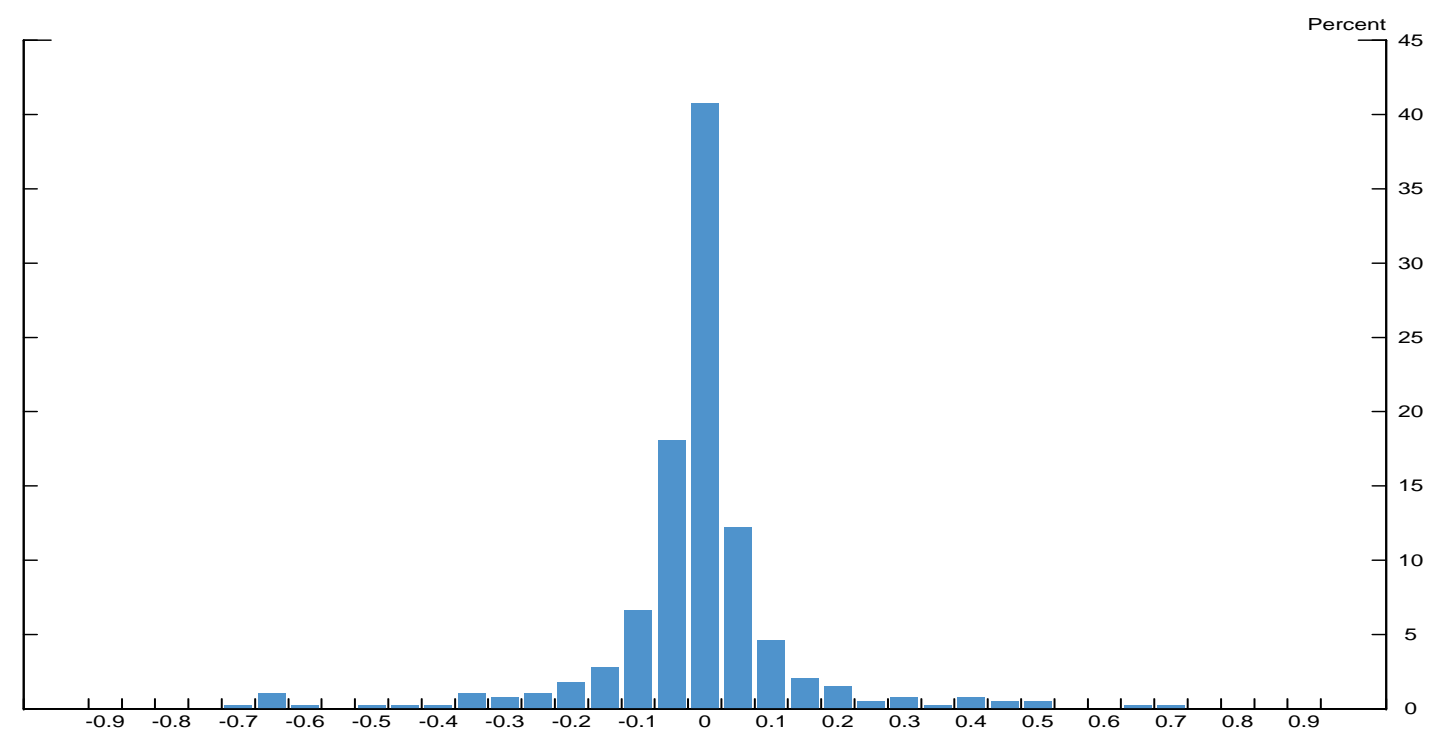

(b) Post-June-2005 Subsample

NoтE: shares are calculated from our constructed dataset based on reported prices. 
Figure 6: Share of Price Changes in Each Month

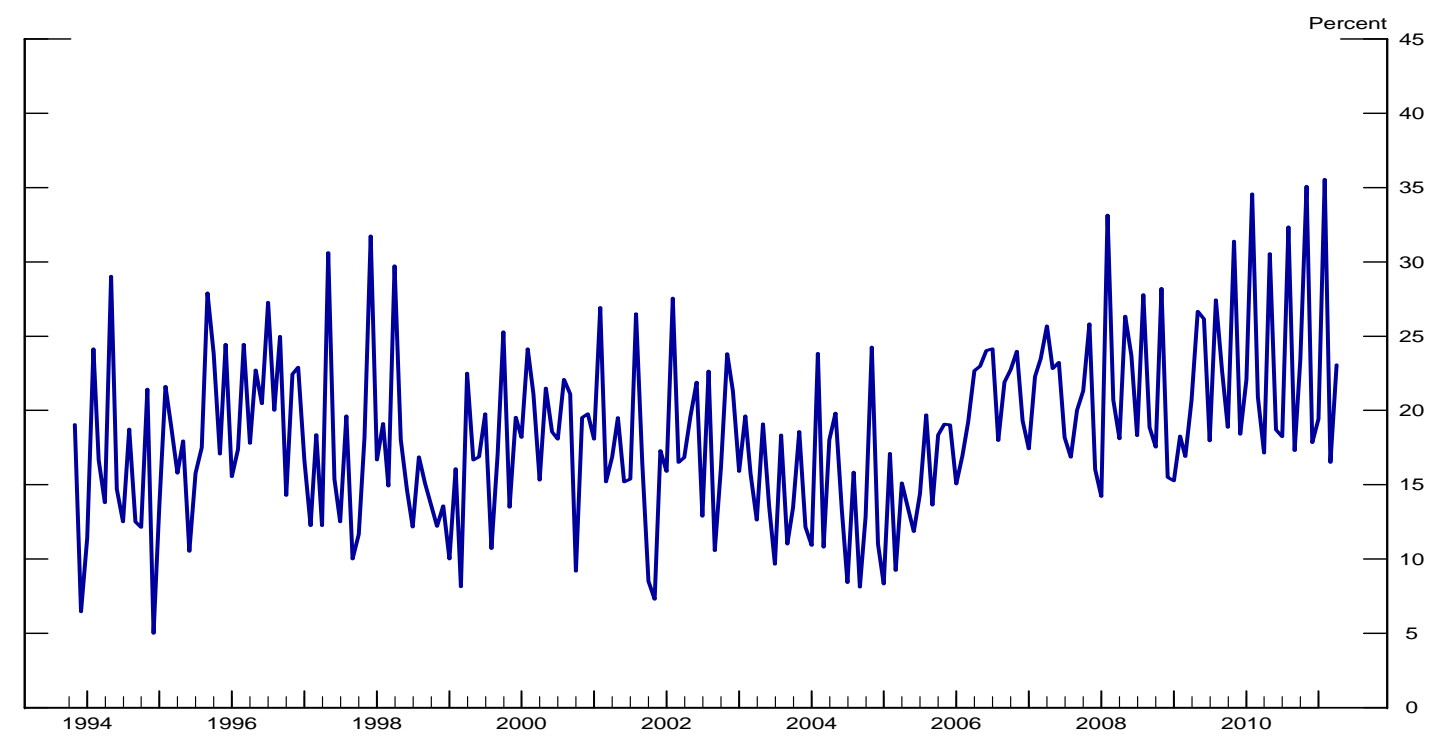

(a) US Exports to China

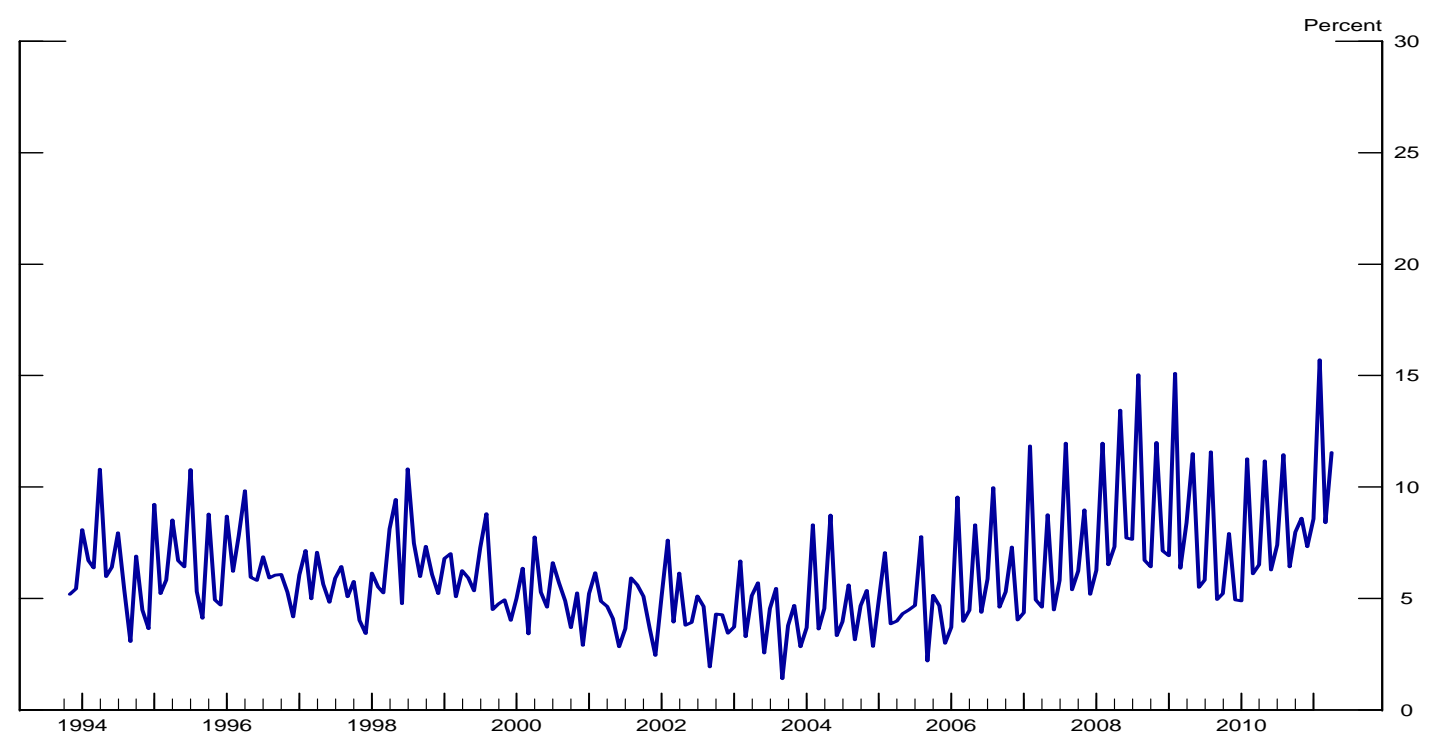

(b) US Imports from China

Note: shares are calculated from our constructed dataset based on reported prices. 
Figure 7: Fraction of Price Changes by Sectors (US Exports to China)

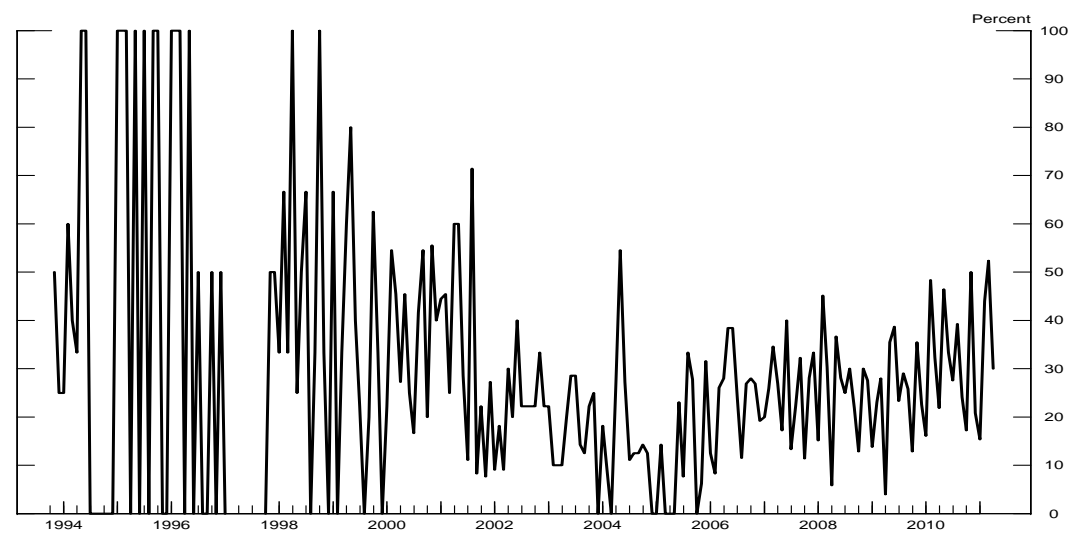

(a) Sector 6: Wood and Wood Products

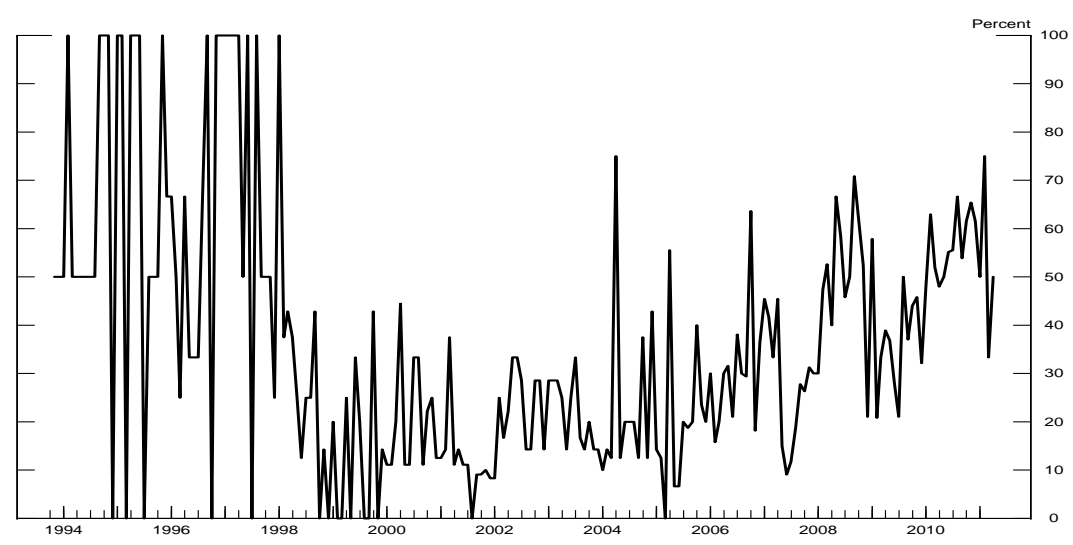

(b) Sector 9: Metals

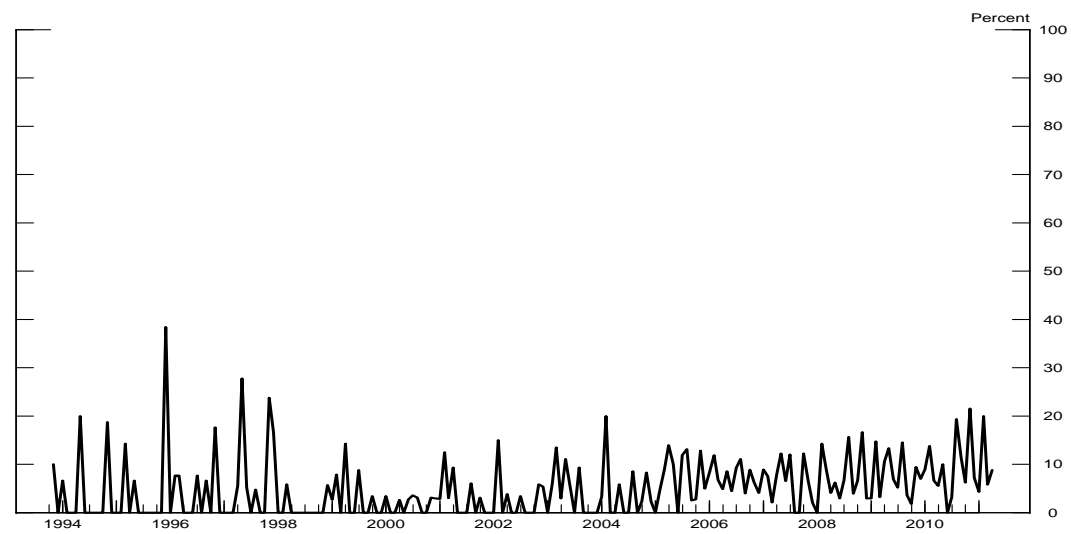

(c) Sector 10: Machinery/Electrical 
Figure 8: Fraction of Prices that Change in Each Month by Sectors (US Imports from China)

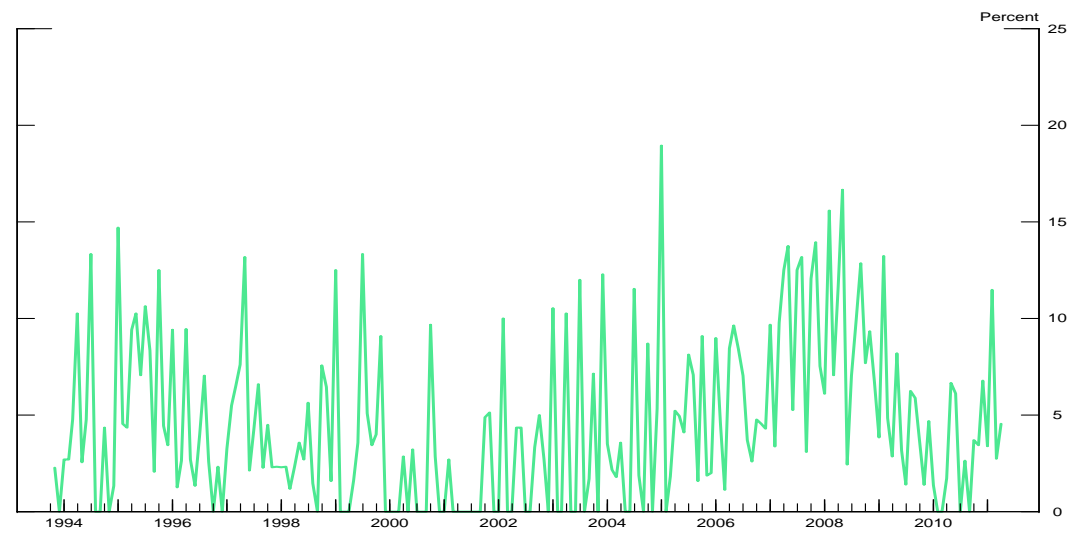

(a) Sector 5: Chemical and Allied Industries, Plastics, and Rubber

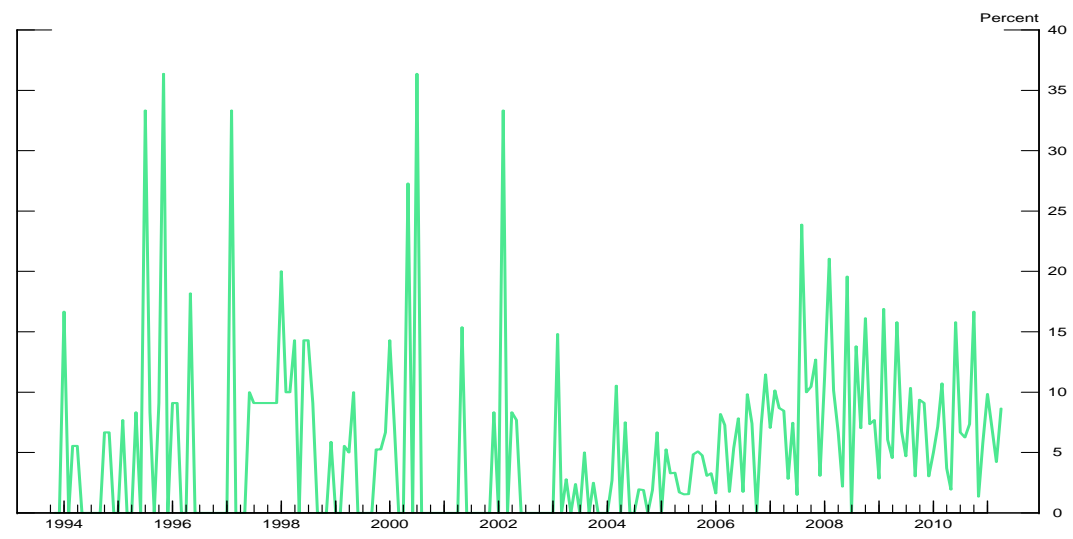

(b) Sector 6: Rawhide, Skins, Leather, and Furs

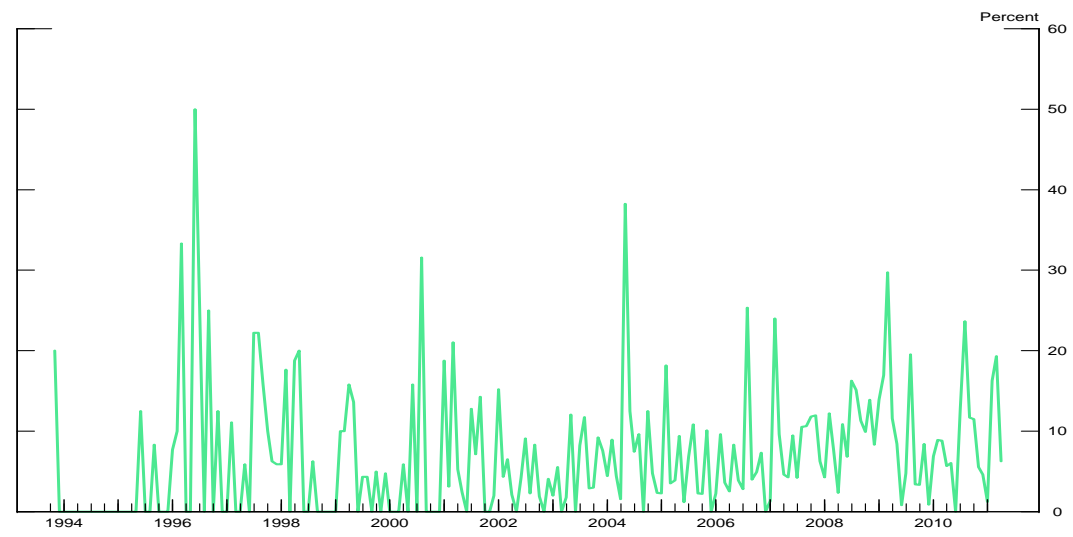

(c) Sector 11: Machinery/Electrical 
Table 1: Summary Statistics

\begin{tabular}{|c|c|c|c|c|c|c|c|c|c|}
\hline & \multirow{2}{*}{$\begin{array}{l}\text { Number of } \\
\text { goods }\end{array}$} & \multirow{2}{*}{$\begin{array}{c}\text { Number of } \\
\text { prices }\end{array}$} & \multicolumn{3}{|c|}{ Goods duration (months) } & \multicolumn{3}{|c|}{ Price changes for each good } & \multirow{2}{*}{$\begin{array}{c}\text { Goods with } \\
\text { no price change }\end{array}$} \\
\hline & & & $\min$ & $\max$ & mean & $\min$ & $\max$ & mean & \\
\hline \multicolumn{10}{|c|}{ US Imports from China } \\
\hline Reported & 14,547 & 336,037 & 1 & 125 & 23.63 & 0 & 55 & 1.68 & $41.69 \%$ \\
\hline Net exclusive & 14,538 & 335,917 & 1 & 125 & 23.58 & 0 & 75 & 1.79 & $41.48 \%$ \\
\hline \multicolumn{10}{|c|}{ US Exports to China } \\
\hline Reported & 1,048 & 24,261 & 1 & 139 & 24.25 & 0 & 80 & 5.15 & $29.29 \%$ \\
\hline Net exclusive & 1,047 & 24,228 & 1 & 139 & 24.23 & 0 & 80 & 5.23 & $27.89 \%$ \\
\hline
\end{tabular}

Note:

-This table reports summary statistics for prices of US imports from and exports to China.

-Reported is the reported prices and net exclusive is net prices excluding estimated and imputed prices by the BLS. See the section of data description for more information on these prices.

-Our data are monthly observations from September 1993 to March 2011. 
Table 2: Price Rigidity of US-China Trade Goods

\begin{tabular}{|c|c|c|c|c|c|c|}
\hline \multicolumn{7}{|c|}{ US Exports to China } \\
\hline & \multicolumn{2}{|c|}{ Whole Sample } & \multicolumn{2}{|c|}{ Pre-June-2005 } & \multicolumn{2}{|c|}{ Post-June-2005 } \\
\hline & $\begin{array}{c}\text { All } \\
\text { goods }\end{array}$ & $\begin{array}{l}\text { At least } \\
1 \text { change }\end{array}$ & $\begin{array}{c}\text { All } \\
\text { goods }\end{array}$ & $\begin{array}{l}\text { At least } \\
1 \text { change }\end{array}$ & $\begin{array}{c}\text { All } \\
\text { goods }\end{array}$ & $\begin{array}{l}\text { At least } \\
1 \text { change }\end{array}$ \\
\hline $\begin{array}{c}\text { Frequency (\%) } \\
\text { Mean } \\
\text { Median }\end{array}$ & $\begin{array}{c}14.11 \\
5.88\end{array}$ & $\begin{array}{l}21.25 \\
11.11\end{array}$ & $\begin{array}{c}11.79 \\
4.76\end{array}$ & $\begin{array}{l}19.21 \\
10.62\end{array}$ & $\begin{array}{c}16.30 \\
7.14\end{array}$ & $\begin{array}{l}25.20 \\
14.29\end{array}$ \\
\hline $\begin{array}{c}\text { Duration (months) } \\
\text { Mean } \\
\text { Median }\end{array}$ & $\begin{array}{c}6.57 \\
16.50\end{array}$ & $\begin{array}{l}4.19 \\
8.49\end{array}$ & $\begin{array}{c}7.97 \\
20.50\end{array}$ & $\begin{array}{l}4.69 \\
8.91\end{array}$ & $\begin{array}{c}5.62 \\
13.50\end{array}$ & $\begin{array}{l}3.44 \\
6.49 \\
\end{array}$ \\
\hline $\begin{array}{c}\text { Fraction up (\%) } \\
\text { Mean } \\
\text { Median } \\
\end{array}$ & \multicolumn{2}{|c|}{$\begin{array}{l}59.03 \\
62.50\end{array}$} & \multicolumn{2}{|c|}{$\begin{array}{l}54.03 \\
50.00\end{array}$} & \multicolumn{2}{|c|}{$\begin{array}{l}63.59 \\
66.67\end{array}$} \\
\hline $\begin{array}{c}\text { Size of Changes (\%) } \\
\text { Mean } \\
\text { Median } \\
\end{array}$ & \multicolumn{2}{|c|}{$\begin{array}{c}15.36 \\
8.48 \\
\end{array}$} & \multicolumn{2}{|c|}{$\begin{array}{c}10.40 \\
7.32 \\
\end{array}$} & \multicolumn{2}{|c|}{$\begin{array}{c}17.90 \\
8.60 \\
\end{array}$} \\
\hline \multicolumn{7}{|c|}{ US Imports from China } \\
\hline & \multicolumn{2}{|c|}{ Whole Sample } & \multicolumn{2}{|c|}{ Pre-June-2005 } & \multicolumn{2}{|c|}{ Post-June-2005 } \\
\hline & $\begin{array}{c}\text { All } \\
\text { goods }\end{array}$ & $\begin{array}{l}\text { At least } \\
1 \text { change }\end{array}$ & $\begin{array}{c}\text { All } \\
\text { goods }\end{array}$ & $\begin{array}{l}\text { At least } \\
1 \text { change }\end{array}$ & $\begin{array}{c}\text { All } \\
\text { goods }\end{array}$ & $\begin{array}{l}\text { At least } \\
1 \text { change }\end{array}$ \\
\hline $\begin{array}{c}\text { Frequency (\%) } \\
\text { Mean } \\
\text { Median }\end{array}$ & $\begin{array}{l}7.65 \\
4.42\end{array}$ & $\begin{array}{c}12.43 \\
9.09\end{array}$ & $\begin{array}{l}6.09 \\
3.03\end{array}$ & $\begin{array}{c}11.43 \\
8.37\end{array}$ & $\begin{array}{l}8.38 \\
4.89\end{array}$ & $\begin{array}{l}14.22 \\
10.26\end{array}$ \\
\hline $\begin{array}{c}\text { Duration (months) } \\
\text { Mean } \\
\text { Median }\end{array}$ & $\begin{array}{l}12.57 \\
22.12\end{array}$ & $\begin{array}{c}7.53 \\
10.49\end{array}$ & $\begin{array}{l}15.92 \\
32.50\end{array}$ & $\begin{array}{c}8.24 \\
11.44\end{array}$ & $\begin{array}{l}11.43 \\
19.95\end{array}$ & $\begin{array}{l}6.52 \\
9.24\end{array}$ \\
\hline $\begin{array}{c}\text { Fraction up (\%) } \\
\text { Mean } \\
\text { Median }\end{array}$ & & $\begin{array}{l}6.24 \\
7.14\end{array}$ & & $\begin{array}{l}7.58 \\
.00\end{array}$ & & $\begin{array}{l}4.15 \\
6.67\end{array}$ \\
\hline $\begin{array}{c}\text { Size of Changes (\%) } \\
\text { Mean } \\
\text { Median }\end{array}$ & & $\begin{array}{l}2.18 \\
.94\end{array}$ & & $\begin{array}{l}.90 \\
.53\end{array}$ & & $\begin{array}{l}2.73 \\
.13\end{array}$ \\
\hline
\end{tabular}

Note:

-The data are monthly observations from September 1993 to March 2011 and the statistics are calculated from reported prices.

- To calculate the mean and median frequencies, we first find the frequency of each entry level item (ELI). Then the unweighted mean and median of frequencies across ELIs are calculated. -Duration is calculated from $d=-1 / \ln (1-f)$, where $f$ is frequency and $d$ is frequencyimplied duration.

-Fraction up is the fraction of price increases in total price changes.

-Size of changes is measured by the absolute value of percentage price changes.

-Columns "All goods" include all goods in our sample. Columns "At least 1 change" only include goods that have at least one price change in their lifetime. 
Table 3: Results of Structural Break Tests

\begin{tabular}{l|c|c|c|c}
\hline \hline \multicolumn{5}{c}{ US Exports to China } \\
\hline & Regime & Regime Date & $a_{j}$ & $b_{j}$ \\
\hline Mean Model & 1 & Oct 1993-Oct 2002 & $.177^{* * *}$ & NA \\
& 2 & Nov 2002-Nov 2005 & $.149^{* * *}$ & NA \\
& 3 & Dec 2005-Mar 2011 & $.223^{* * *}$ & NA \\
\hline Trend Model & 1 & Oct 1993-Oct 2005 & $.184^{* * *}$ & $-.040^{* *}$ \\
& 2 & Nov 2005-Mar 2011 & $.142^{* * *}$ & .093 \\
\hline
\end{tabular}

US Imports from China

\begin{tabular}{c|c|c|c|c}
\hline & Regime & Regime Date & $a_{j}$ & $b_{j}$ \\
\hline Mean Model & 1 & Oct 1993-Apr 1999 & $.064^{* * *}$ & NA \\
& 2 & May 1999-Mar 2007 & $.048^{* * *}$ & NA \\
& 3 & Apr 2007-Mar 2011 & $.082^{* *}$ & NA \\
\hline Trend Model & 1 & Oct 1993-Sep 2005 & $.069^{* * *}$ & $-.040^{* * *}$ \\
& 2 & Oct 2005-Mar 2011 & -.005 & $.098^{* * *}$ \\
\hline \hline
\end{tabular}

Note:

-This table reports the results of structural break tests for price stickiness of US trade with China.

- Superscripts $* * *$, and $* * *$ denote statistical significance at $10 \%, 5 \%$, and $1 \%$, respectively.

Table 4: Median Price Durations (months) at Sectoral Level

\begin{tabular}{|c|c|c|c|c|}
\hline Sector & & Whole Sample & Pre-June-2005 & Post-June-2005 \\
\hline 1 & Animals, Animals and Vegetable Products & 2.29 & 1.66 & 2.54 \\
\hline 2 & Prepared Foodstuff & 4.64 & 10.42 & 3.19 \\
\hline 3 & Mineral Products & 9.99 & 9.99 & 4.42 \\
\hline 4 & Chemical and Allied Industries, Plastics, and Rubber & 6.99 & 8.89 & 4.65 \\
\hline 5 & Rawhide, Skins, Leather, and Furs & 1.55 & 2.29 & 1.50 \\
\hline 6 & Wood and Wood Products & 3.49 & 2.47 & 3.16 \\
\hline 7 & Textile and Footwear/Headgear & 7.49 & 2.60 & 7.73 \\
\hline 8 & Stone/Glass & 19.40 & 56.51 & 16.50 \\
\hline 9 & Metals & 2.80 & 4.48 & 1.64 \\
\hline 10 & Machinery/Electrical & 13.49 & 15.99 & 10.83 \\
\hline 11 & Transportation & 10.79 & 20.50 & 4.48 \\
\hline 12 & Miscellaneous & 14.24 & 8.32 & 12.39 \\
\hline
\end{tabular}

Note:

-This table reports sectoral-level median durations of US exports to China. Durations are calculated from $d=-1 / \ln (1-f)$, where $f$ is frequency and $d$ is frequency-implied duration. The sectors are aggregations at the 2-digit level HS codes.

-The statistics are calculated from reported prices of goods that have at least one price change.

-The data are monthly observations from September 1993 to March 2011. 
Table 5: Menu Cost Model

\begin{tabular}{c|c|c|c|c|c|c}
\hline \hline & \multicolumn{2}{|c|}{ Pre-June-2005 } & \multicolumn{4}{c}{ Post-June-2005 } \\
\hline & Data & Model & Data & Benchmark & Only $P_{U S, t}$ & Only $\tau_{t}$ \\
\hline Share of price changes (\%) & 10.6 & 10.6 & 14.3 & 15.9 & 13.5 & 12.9 \\
Fraction of price increases (\%) & 50 & 50 & 67 & 57 & 58 & 50 \\
Size of price changes (\%) & 7.2 & 7.6 & 8.5 & 8.2 & 8.6 & 7.4 \\
\hline$\mu$ & & 1.000 & & 1.002 & 1.002 & 1.000 \\
$\sigma_{\eta}$ & & 0.009 & & 0.019 & 0.019 & 0.009 \\
$\nu$ & & 0.79 & & 0.19 & 0.79 & 0.19 \\
$\phi$ & & 0.885 & & 0.971 & 0.885 & 0.971 \\
$\sigma_{\tau}$ & & 0.010 & & 0.014 & 0.010 & 0.014 \\
\hline$\alpha$ & & 0.93 & & 0.93 & 0.93 & 0.93 \\
$\theta$ & & $0.96^{1 / 12}$ & & $0.96^{1 / 12}$ & $0.96^{1 / 12}$ & $0.96^{1 / 12}$ \\
$\rho$ & & 4 & & 4 & 4 & 4 \\
$\sigma_{\varepsilon}$ & & 0.76 & & 0.76 & 0.76 & 0.76 \\
$K$ & & 0.0335 & & 0.0335 & 0.0335 & 0.0335 \\
$(1-\alpha) \tau^{-\alpha} C_{M}$ & & 0.00022 & & 0.00022 & 0.00022 & 0.00022 \\
\hline \hline
\end{tabular}

Note:

-The pre-June-2005 subsample is from January 1996 to June 2005 and the post-June-2005 subsample is from July 2005 to March 2011.

-The share of price changes (\%) in the data is the median share of price changes in each month during each subsample. The fraction of price increases (\%) is the median fraction of price increases in all prices changes during each subsample. The size of price changes (\%) is the median absolute size of price changes.

-Parameters $\mu$ and $\sigma_{\eta}$ are estimated from the data of the US export price index to China, which is assumed to follow a process of $\log \left(P_{U S, t}\right)=\mu+\log \left(P_{U S, t-1}\right)+\eta_{t} \cdot \sigma_{\eta}$ is the standard deviation of $\eta_{t}$.

-Parameters $\nu, \phi$, and $\sigma_{\tau}$ are estimated from the data of $\tau_{t}$, which is assumed to follow an $\mathrm{AR}(1)$ process: $\log \left(\tau_{t}\right)=\nu+\phi \log \left(\tau_{t-1}\right)+\varepsilon_{\tau, t} . \sigma_{\tau}$ is the standard deviation of $\varepsilon_{\tau, t}$.

-All other parameters are calibrated and see section 3 for the details of calibration.

Table 6: Lifelong Exchange Rate Pass-through (ERPT)

\begin{tabular}{c|ccc|ccc}
\hline \hline & \multicolumn{3}{|c|}{ All Prices } & \multicolumn{3}{c}{ 1 or More Price Changes } \\
\hline & ERPT & s.e. & $\mathrm{N}$ & ERPT & s.e. & $\mathrm{N}$ \\
\hline Reported Prices & 0.39 & 0.41 & 5177 & 0.88 & 0.86 & 2435 \\
Net Prices Exclusive & 0.48 & 0.41 & 5180 & 1.02 & 0.87 & 2412 \\
\hline & 1 or 2 & Price & Changes & More than 2 Price Changes \\
\hline & ERPT & s.e. & $\mathrm{N}$ & ERPT & s.e. & $\mathrm{N}$ \\
Reported Prices & 0.80 & 1.21 & 1677 & 2.71 & 1.88 & 758 \\
Net Prices Exclusive & 0.99 & 1.28 & 1648 & 2.94 & 1.80 & 764 \\
\hline \hline
\end{tabular}

Note:

-This table reports lifelong ERPT for US imports from China.

- s.e. is the standard error and $\mathrm{N}$ is the number of observations.

-The data are monthly observations from June 2005 to July 2008.

-Column "All Prices" includes all prices in our sample. Column "1 or More Price

Changes" only includes prices that have at least one change in their lifetime.

-Column "1 or 2 price Changes" includes prices with one or two changes and column

"More than 2 Price Changes" includes prices with more than two changes. 